\title{
مقصد إصلاح العالم في القرآن الكريم
}

\section{فريدة حايد*}

\author{
الملخص \\ يهـدف البحـث إلى بيـان حقيقة الإصلاح وأسسـه في القرآن الكريم بوصفه أهـم المقاصد الشـعية وأعظمها؛ \\ فالإصلاح -بما يعني من دفع للفساد، وإحلال للنفع - مقصد قطعي قرآي هدفه حفظ نظام العالم، واستدامة صلاحه \\ بصلاح المهيمن عليه وهو الإنسان. وقد أشار البحث إلى أن أساس الإصلاح الإنساني هو إصلاح التفكير الذي يقود \\ إلى إصلاح الأعمال التي لها أثرها في بناء الحضارة والعمران. \\ الكلمات المفتاحية: القرآن الكويع، إصلاح، مقاصد، نظام العالم.
}

\section{Reform of the World Order as a Qur'anic Intent.}

\section{Farida Hayed}

\begin{abstract}
This paper addresses the nature of reform and its foundations in the Gracious Qur'an, as reform is considered the most important and legitimate intent. Reform (Islah), i.,e. achieve the good and prevent corruption, is a definite Qur'anic intent, to preserve the World order and maintain its good quality through the good quality of Man, the vicegerent.

The paper concludes that the basis of Man's reform is the reform of his thinking that leads to reform of his endeavor to build civilization and development.
\end{abstract}

Keywords: Gracious Qur'an; Reform; Intents; World order.

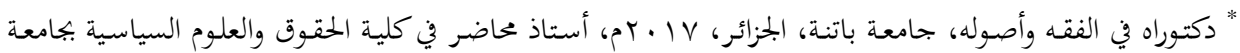

faridahaid@yahoo.fr جيجل - الجزائر. البريد الإلكتروني واصنه

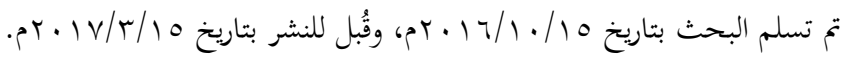


مقدمة:

جاءت تعاليم الإسلام عموماً والقرآن الكريم خاصةً بالتقويم والإصالاح لحالة المجتمع الذي كان سائداً، وحالة الإنسان المهيمن عليه؛ ما يؤكد قيام دعوة القرآن على الإصلاح الشامل لمختلف جوانب الحياة الدينية والدنيوية، حتى غدا مقصداً له؛ بغية إنشاء نظام جديـد يقوم على أسس التعاون والرحمة، ويعنى بإصـالاح الإنسـان وتهيئته لأداء مهامـهـ.

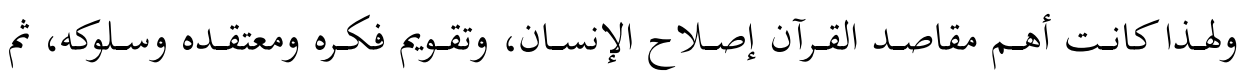
إصـالح بحتمعـه بتقـويم فكره الجماعي وقيمهه، فجـاء الإصـلاح القرآي شـاملاً متكاملاً،

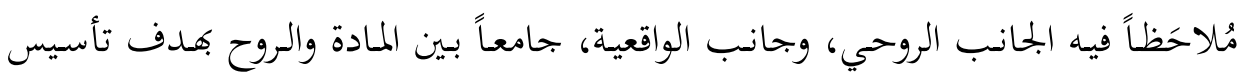
نظام صالح لكل الإنسانية، والبقاع الأرضية.

وقد قـام الإصـلاح القـرآي على الإصـلاح العقـدي لإيجـاد منـاخ فكـري تنطلق منه الإصـالاحات الفرديـة والجماعيـة، فبــأ بإصـالاح العقيـدة والـروح، ثم تــرَّج في إصـلاح السـلوك والـنظم الاجتماعيـة، وبتلَّى في إبحازاتـه، فــاهتم بإصـالاح الأسـرة ونظامهـا،

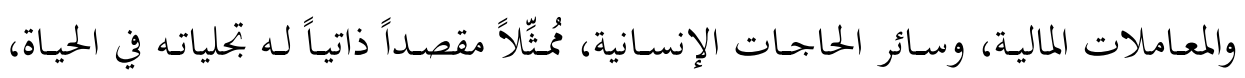
وغـير مفصـول عنها، فكـان مـن مقاصـد الإسـلام عامـةً ومقاصـد القـرآن خاصـةً تطهير

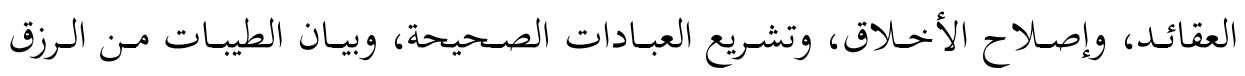

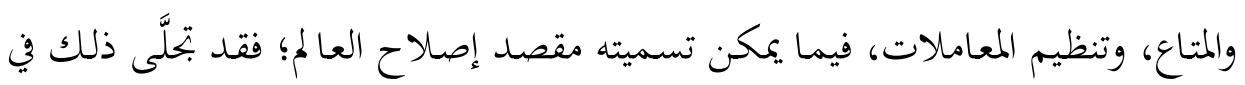
كثير من آياته وأحكامه، ما جعلني أروم جمع هذه الآيات والتأصيلات الواردة فيه ليكون

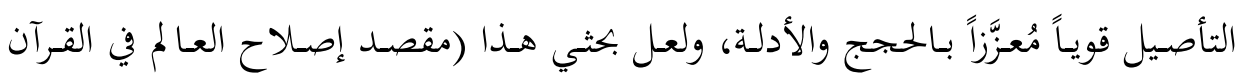

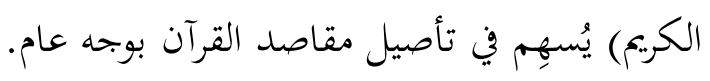
ويمكن ؛إجمال أهمية البحث والهدف منه فيما يأتي: ا ـ الوقوف على أساس الإصلاح في القرآن الكريم. r. الإسهام في وضع قواعد إصلاحية نابعة من القرآن الكريم. 


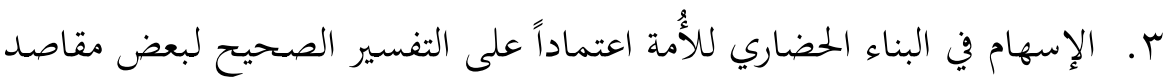
القرآن، ووضع تطبيقات عملية لها.

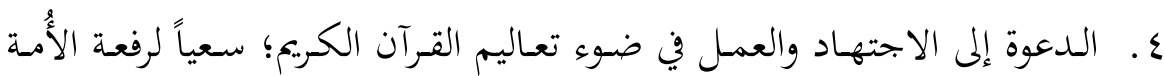
الإسلامية وتقدمها.

واقتضـت طبيعة الموضـوع توظيف المـنهج الاستقرائي أولاً لمعرفـة آيـات الإصـلاح

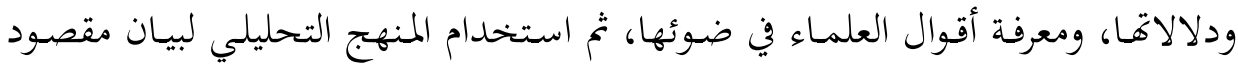
الإصلاح في القرآن الكريع وبحلياته المعاصرة.

\section{أولاً: حقيقة مقصد الإصلاح وأهميته في القرآن الكريم}

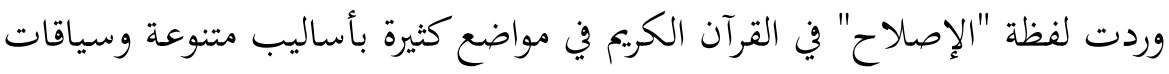

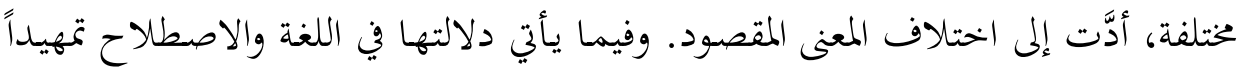

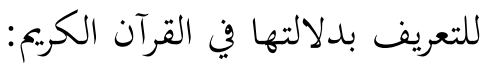

\section{ا ـ تعريف الإصلاح لغةً:}

الإصلاح، ومنه الصلاح، مأخوذ من الفعل صلح ضد فسد، وأصلح ضد ضد أفسد.

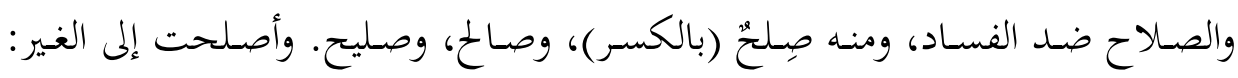

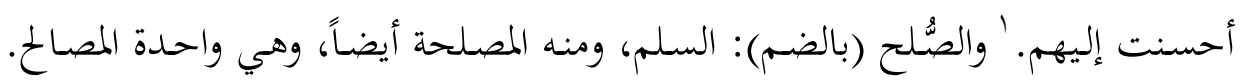

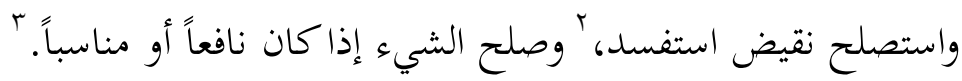
فالإصلاح لغةً: إحلال الصلاح والنفع والخير في النفس أو الغير، فيصبح الشيء نافعاً أو مفيداً.

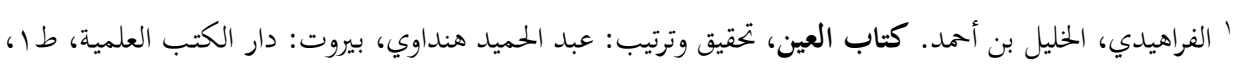

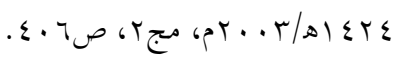

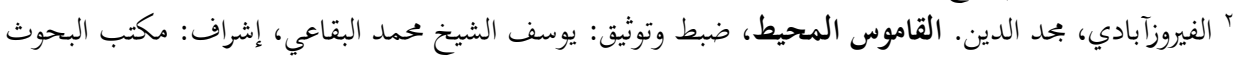

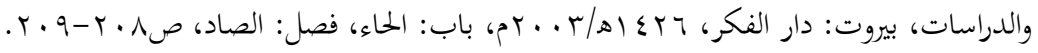

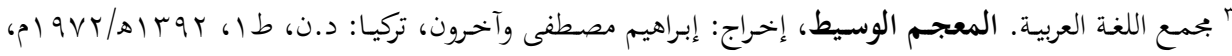
ج) 


\section{r. تعريف الإصلاح اصطلاحاً:}

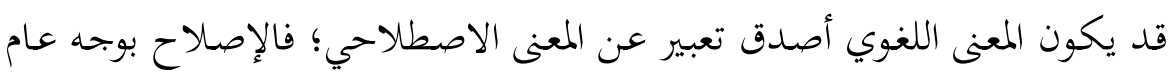

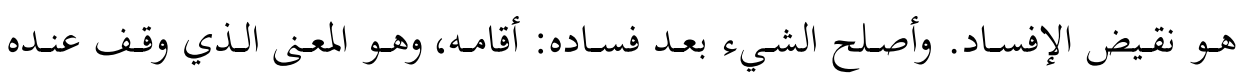

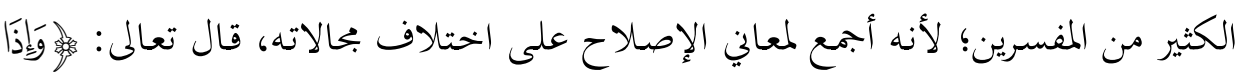

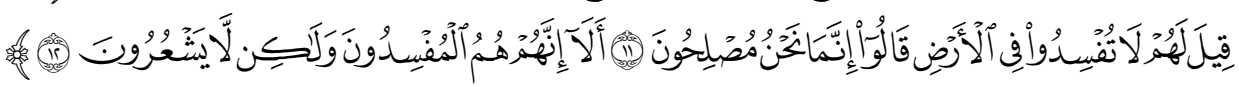

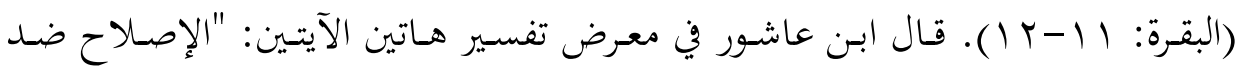

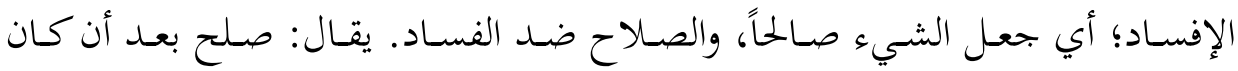

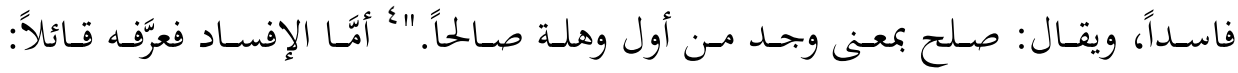

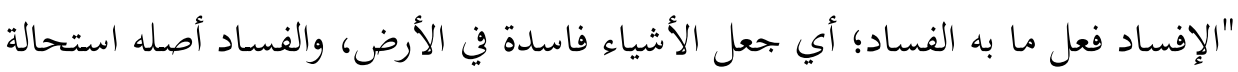

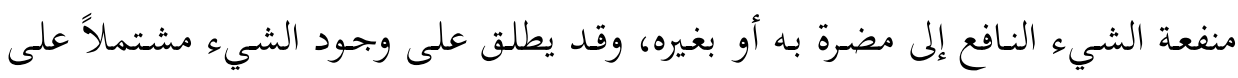

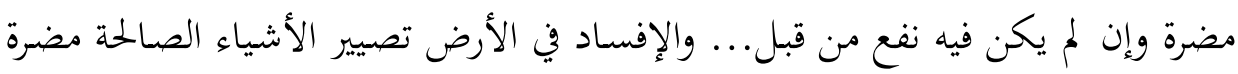

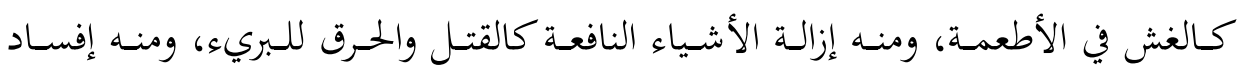

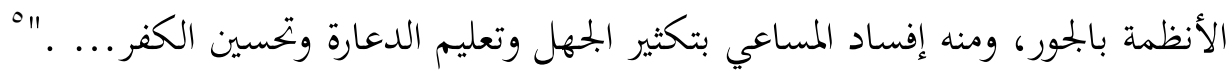

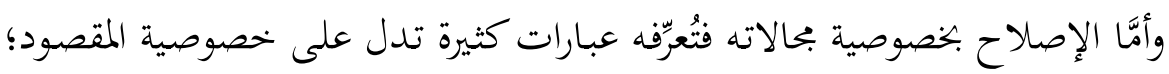

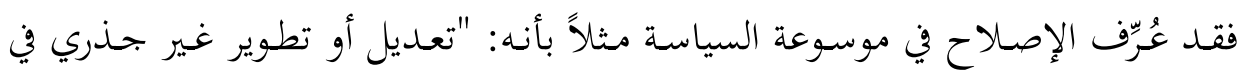

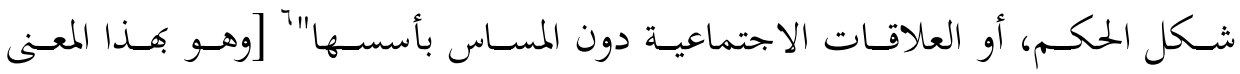

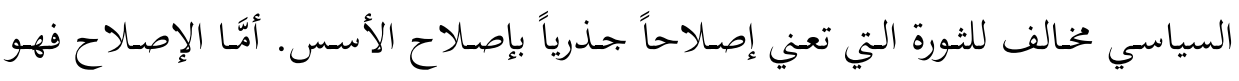

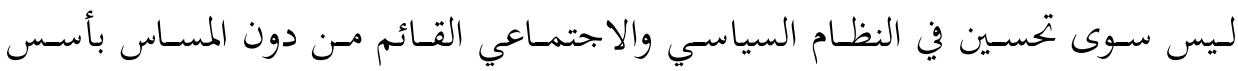

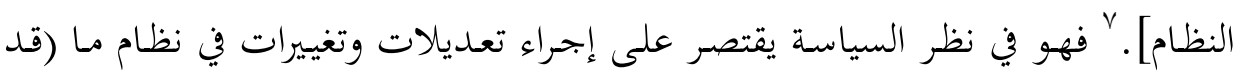

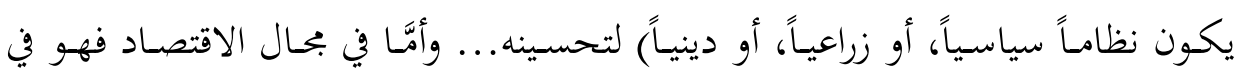

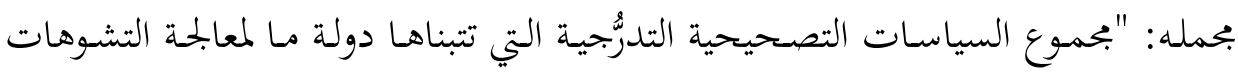

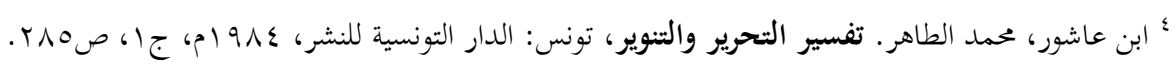

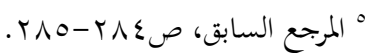

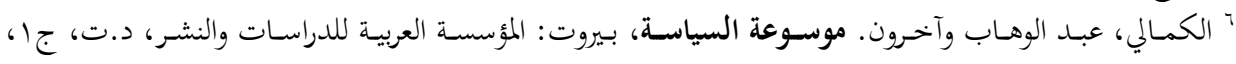


والاختلالات الهيكلية في الاقتصاد، عبر إحداث تغييرات جوهرية في أساليب تعبئة الموارد

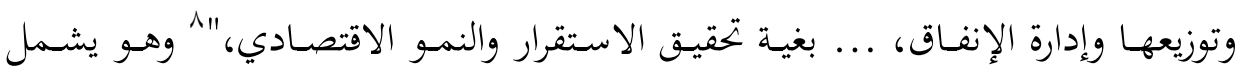

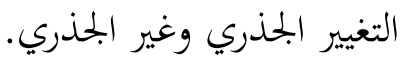

وأمَّا معناه الاجتماعي فيشير إلى "الحركة العامة التي تحاول القضاء على المساوئ التي

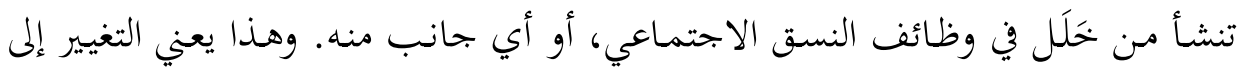

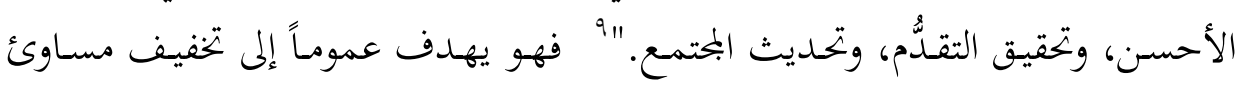

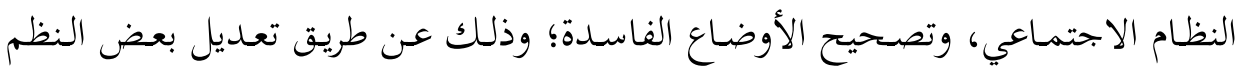

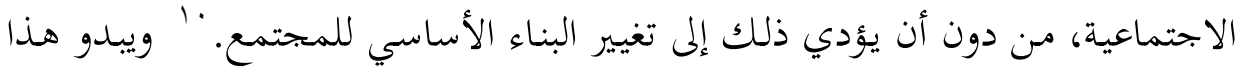

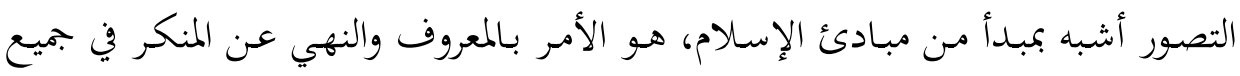

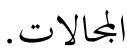

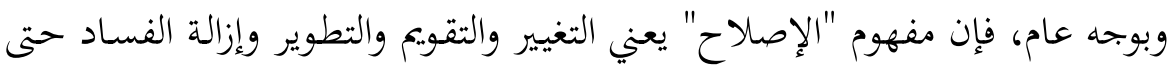

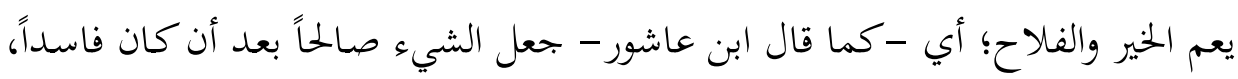

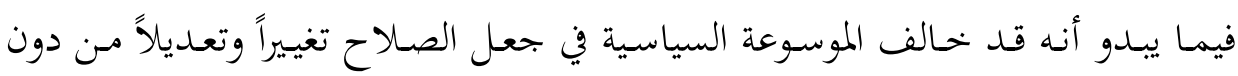

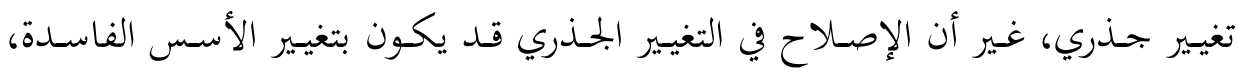

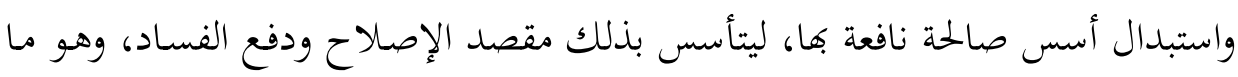

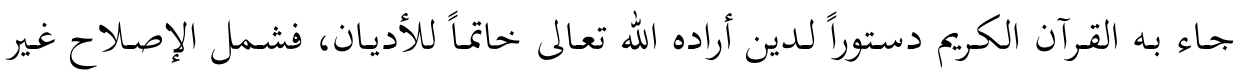

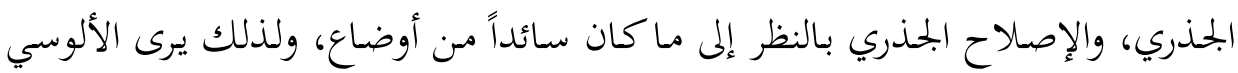

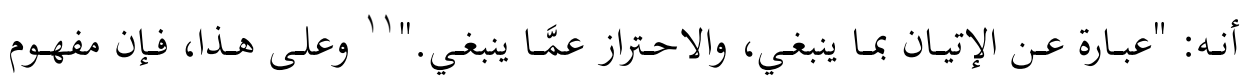

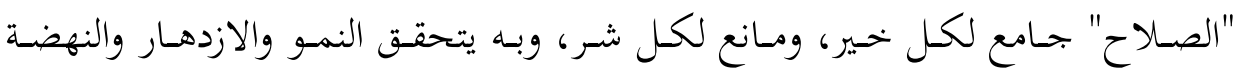

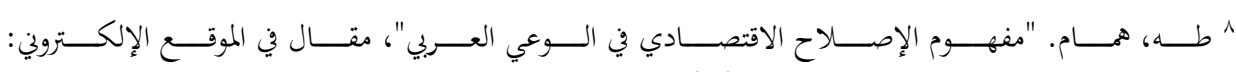

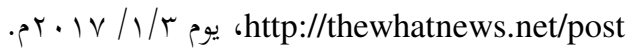

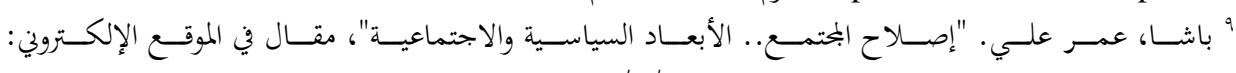

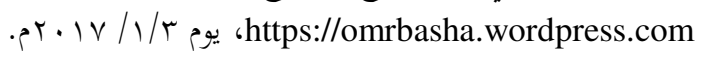

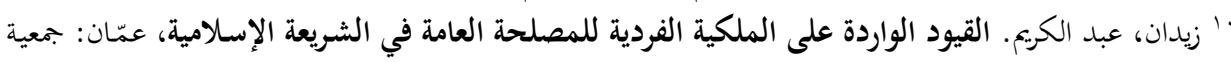

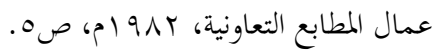
"' الألوسي، محمود أبو الفضل، روح المعاني فئ في تفسير القرآن العظيم والسبع المثاني، بيروت: دار إحياء التراث

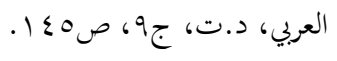


للمجتمع، وهو يمثل مفهوم "الإصلاح الشامل " الذي ينشـه الإسلام، والذي يتـداخل

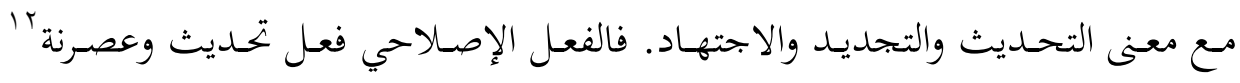
تتعلق بالإنسان والمجتمع، ويشمل جميع نواحي الحياة السياسية والاقتصادية والثقافية. ولو أردنـا استقراء مـادتي "الصـلاح" و "الإصـلاح" في القـرآن الكريم لوجـدنا دستوراً

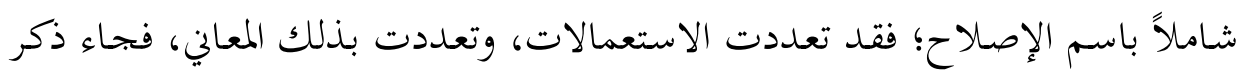

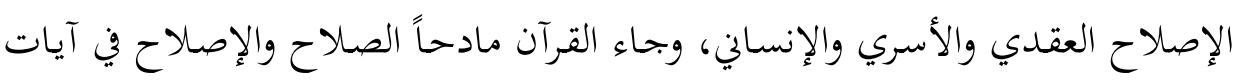

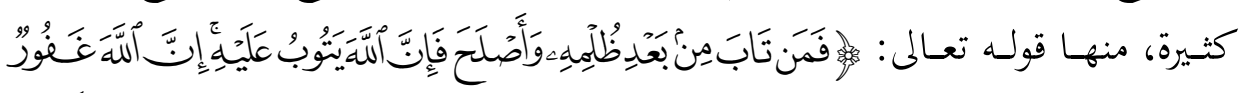

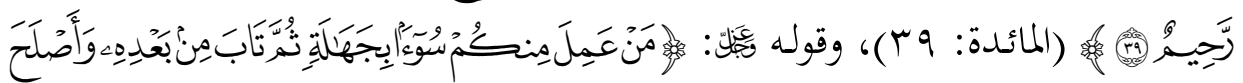

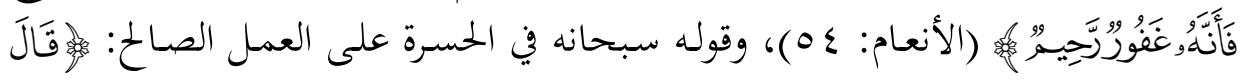

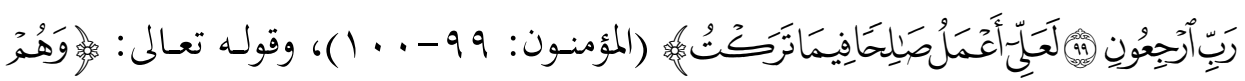

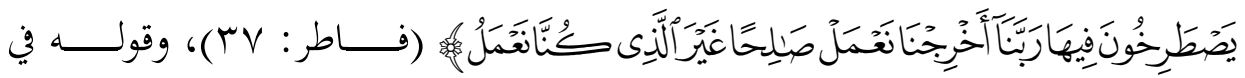

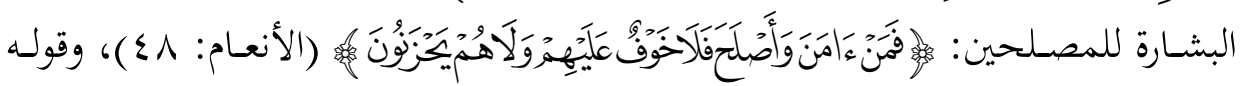

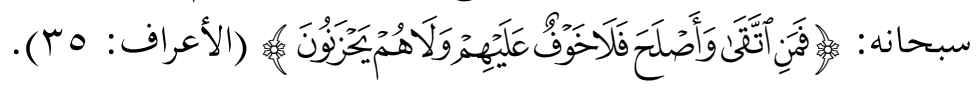
وبالمقابل، فقد حذَّر القرآن الكريم من الفساد والإفساد، ومعلوم مناقضتهما للصالاح

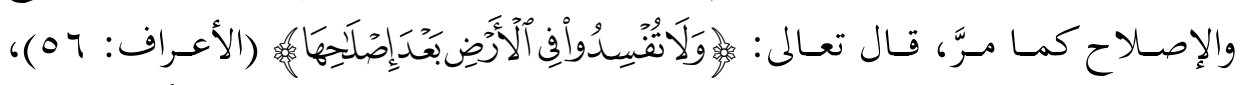

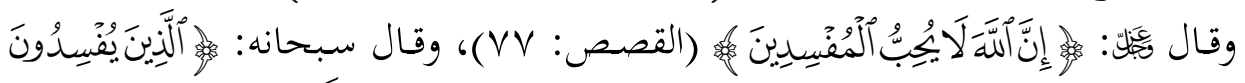

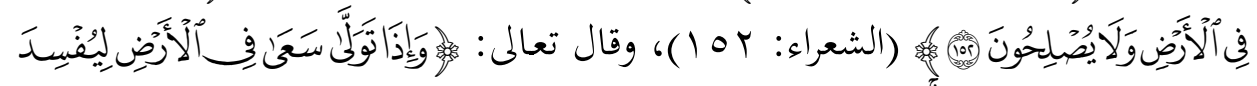

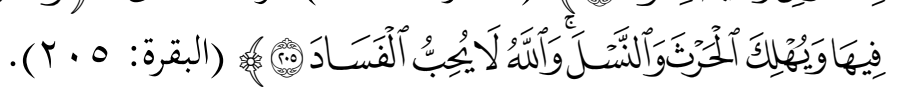

وبذلك يتضح أن الإصلاح مقصد قرآني جاء تأصيله في القرآن الكريم بالإشارة إلى

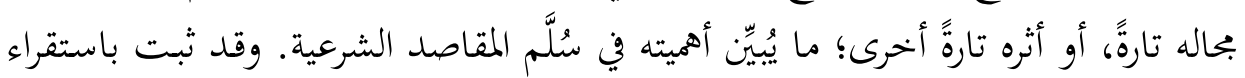

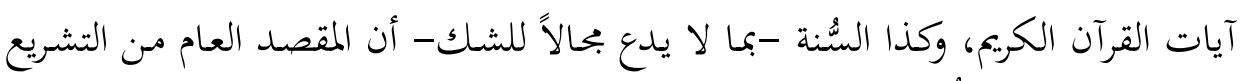

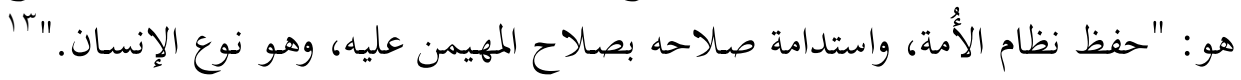

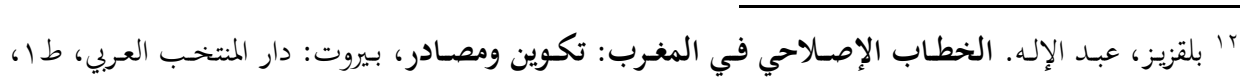

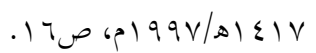

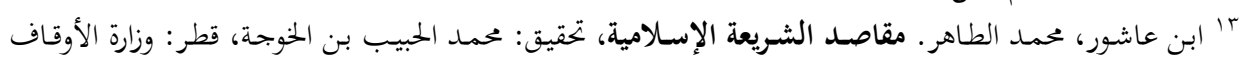

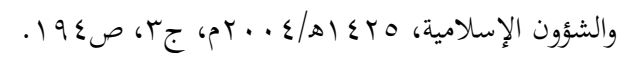




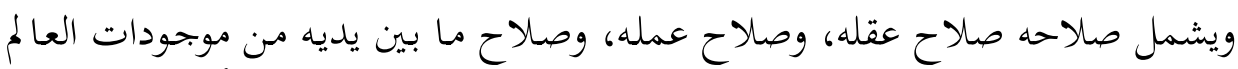

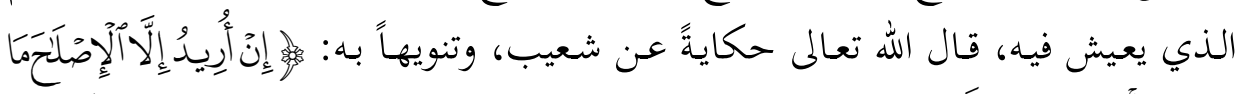

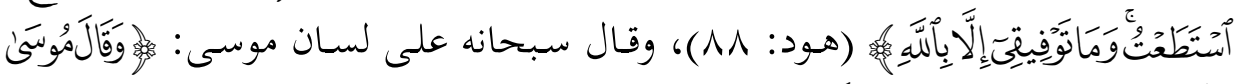

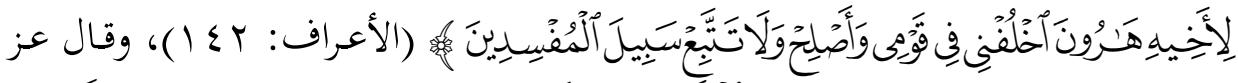

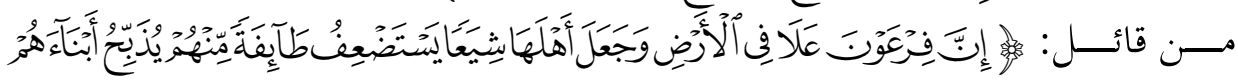

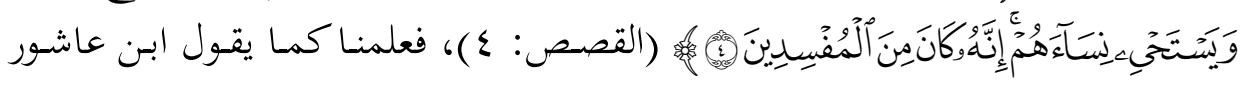

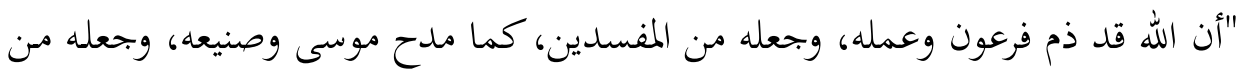

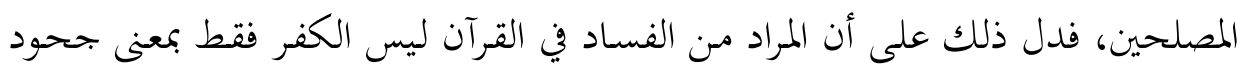

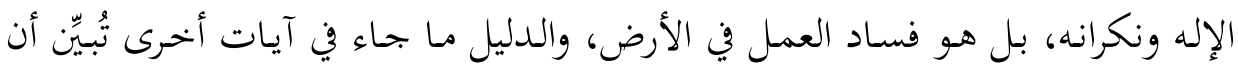

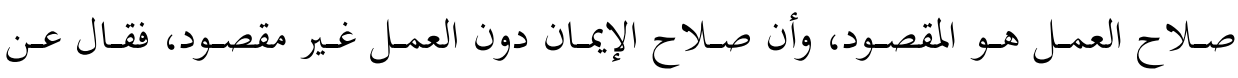

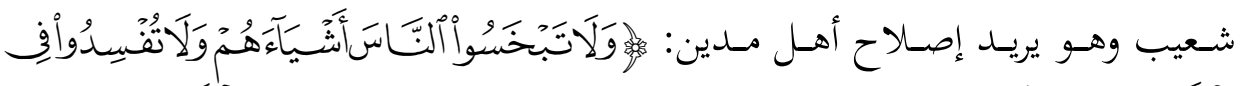

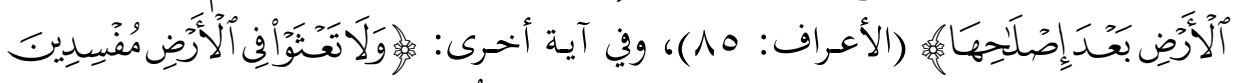

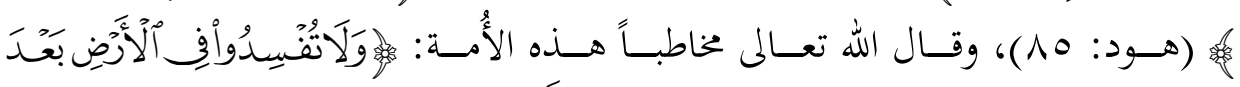

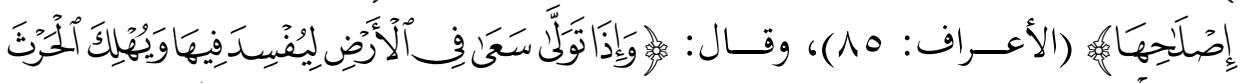

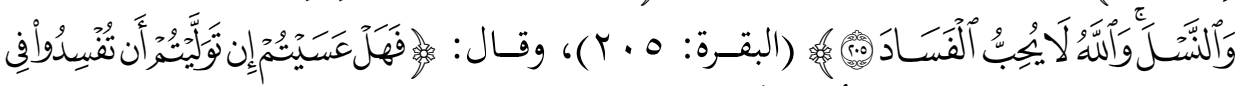

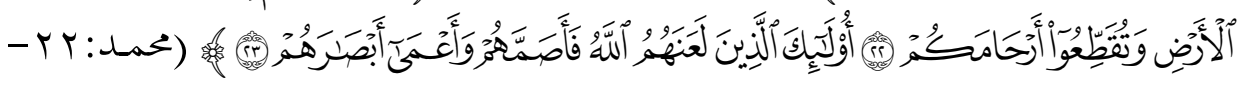
IE".(Y

فهذه آيات بينات تُوضِّح أن مقصود القرآن من إقامة الدين هو الإصلاح، وأنه قَرَنه

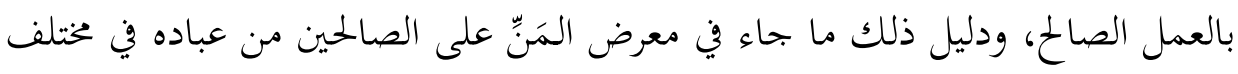

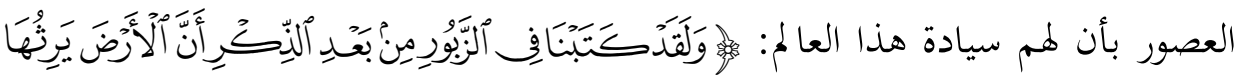

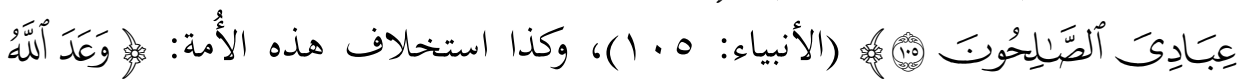

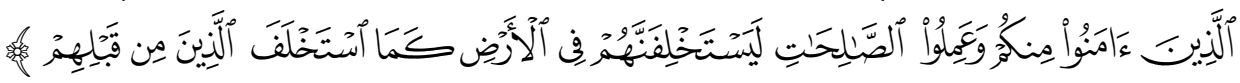

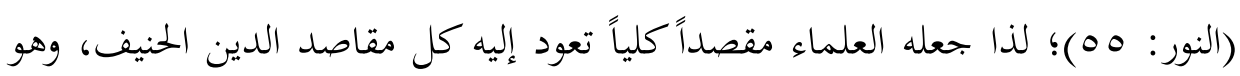

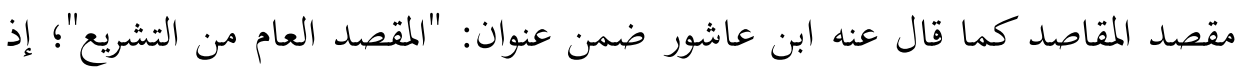


قال: "فقد انتظم لنا الآن أن المقصد الأعظم من الشريعة هو جلب الصلاح ودرء الفساد، وذلك يجصل بإصلاح حال الإنسان، ودفع فساده."

فهذه أدلة صريحة كلية تؤكد أن مقصد الشريعة من إقامة الدين وإنزال القرآن هو

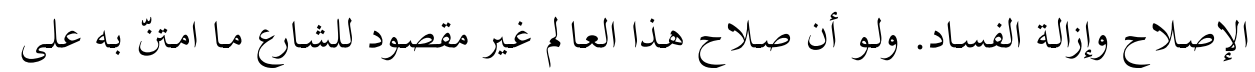

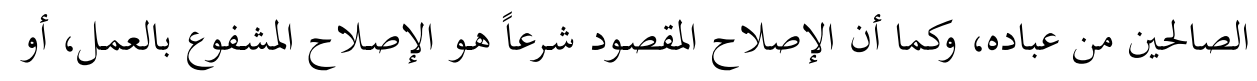

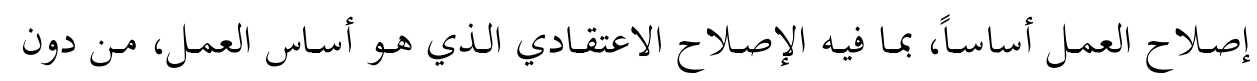

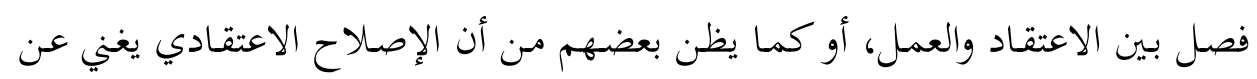

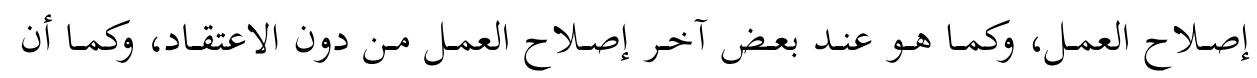

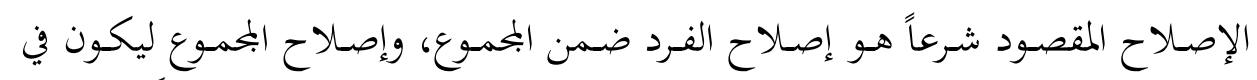

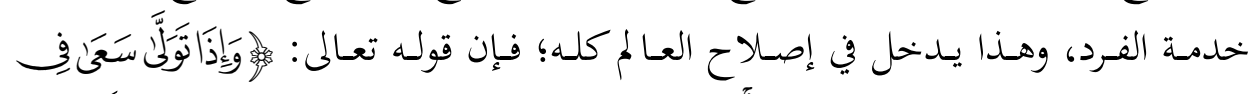

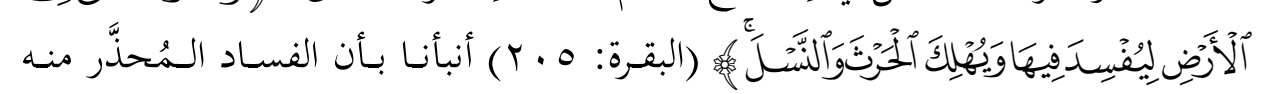
هو إفساد موجودات هذا العالم.

وهكذا يتبـين أن المقصسود مـن إصـلاح العـا لم هـو تحقيـق المصـلحة للنساس أجمعين،

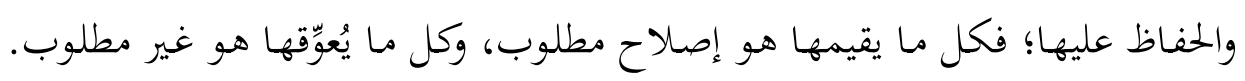

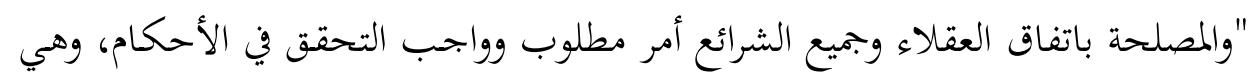

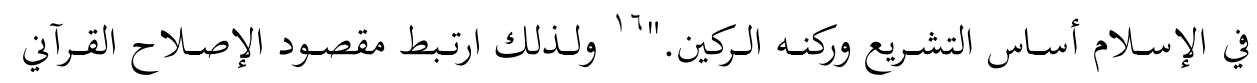

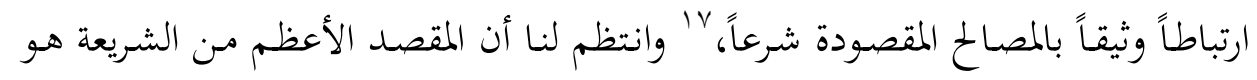
جلب الصلاح، ودرء الفساد، وذلك يكصل بإصلاح حسال الإنسان، ودفع فسـاده، ثم

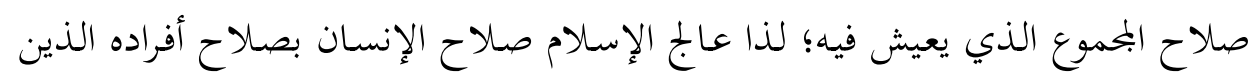

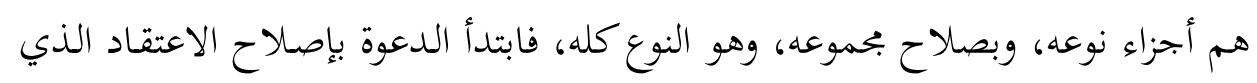

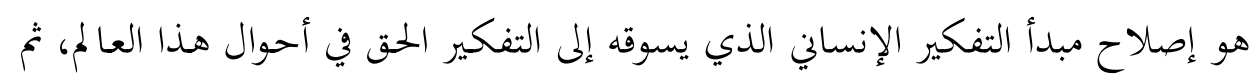
•l ابن عاشور، محمد الطاهر. أصول النظام الاجتماعي في الإسلام، الجزائر -تونس: المؤسسة الوطنية للكتاب،

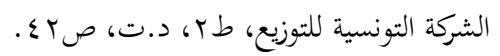

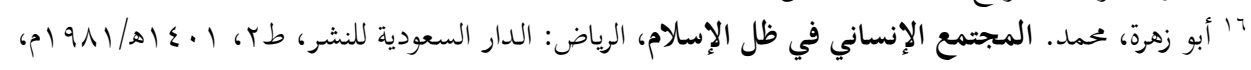
ص V V V V V V

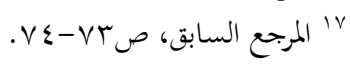


عالج الإنسان بتزكية نفسه، وتصفية باطنه بالأخلاق التي تعد محرك الإنسان إلى الأعمال الصالحة. 11

ثانياً: مقصد إصلاح العالم بتصحيح العقائد والأخلاق

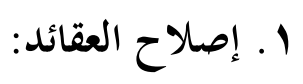

نادى القرآن الكريم بإصلاح الفرد أولاً وآخراً، فدعا إلى تحرير أفكاره وعقائده من

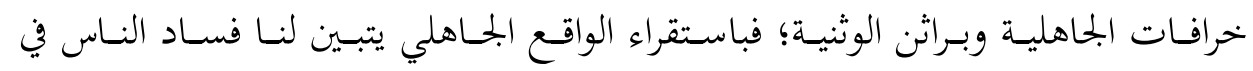

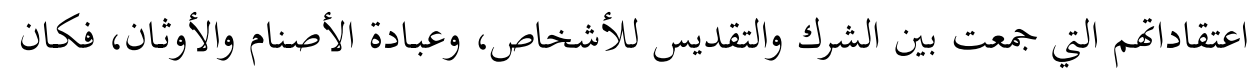

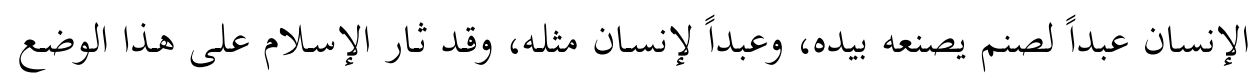

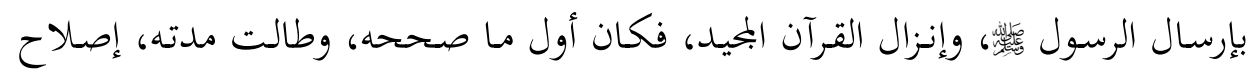

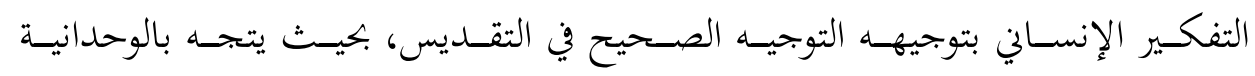

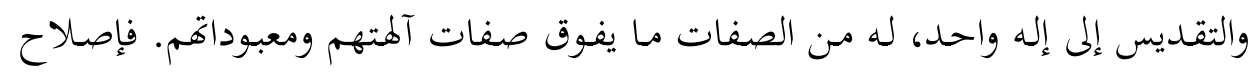
العقيدة في نظر القرآن هو المحرك الأساس لتقبُّل كل صالح ونافع بعده؛ فلا عبودية إلا لله، إلها

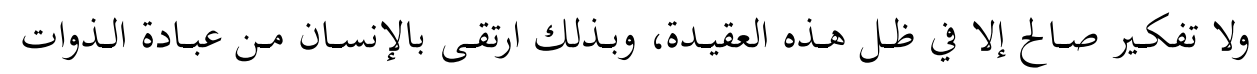

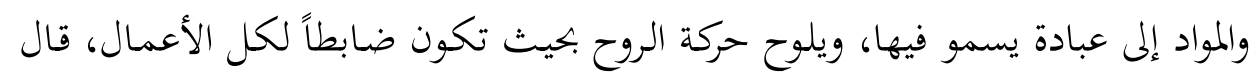

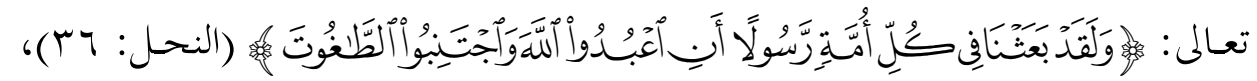

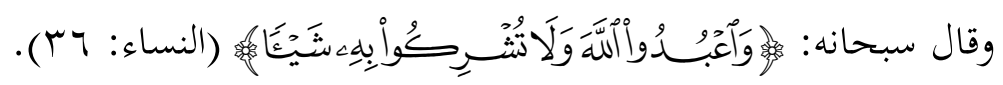
فتحريـر الإنسـان مـن الناحيـة الغيبيـة والروحيـة يمثـل أول فضــة كانـت لـه في ضـوء

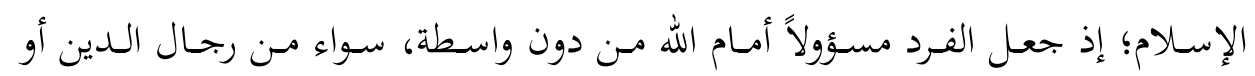

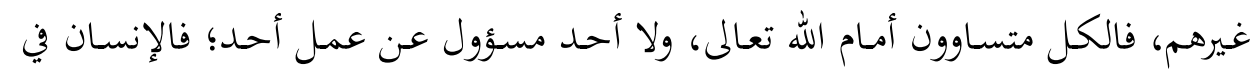

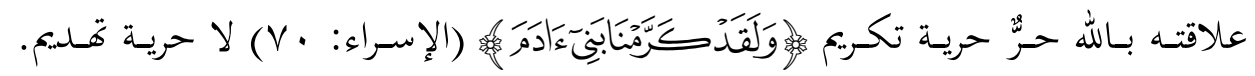

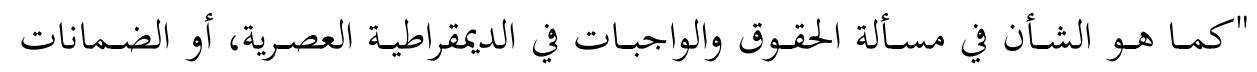

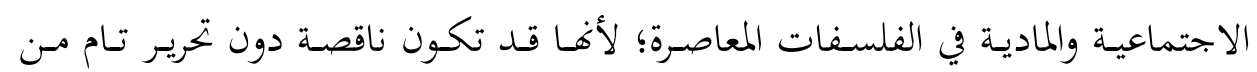

$$
\text { ^` ابن عاشور، مقاصد الشريعة الإسلامية، مرجع سابق، صع } 7 .
$$


عبادة الإنسان لغيره، فقد تتحول هذه الضمانات إلى استعباد أو استغلال. "ا9" وفي هذا الإصلاح القرآني ما يُبيِّن أن أساس قيام الحضارة هو الإنسان نفسه؛ بتكريمه أولاً، وتحريره

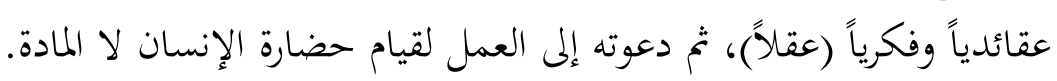
ولتحقيق هذه الأهداف والمقاصد، فقد شرع الله تعالى جملة أحكام تميزت بالوسطية

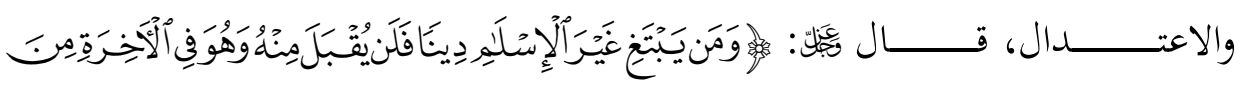

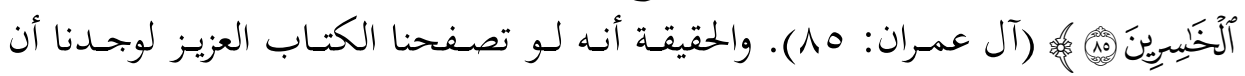
البمتمعات البشرية -على مرّ التاريخ- كانت مصابة بأحد الانحرافين الآتيين: - الانحراف العقدي: وذلك أن العقائد كانت غالباً مقتبسة من غيرهم دون تدبر.

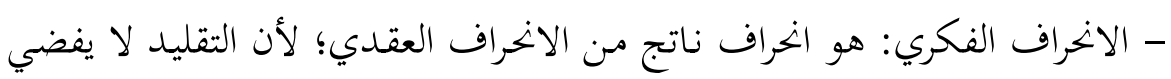
إلى الابتكار والاكتشاف الروحي والمادي.

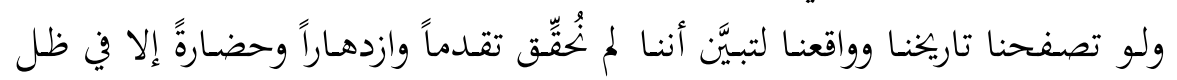

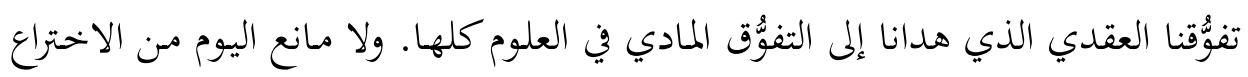

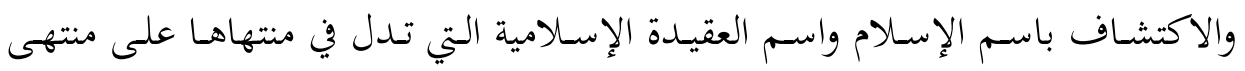

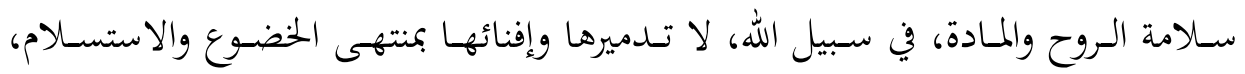

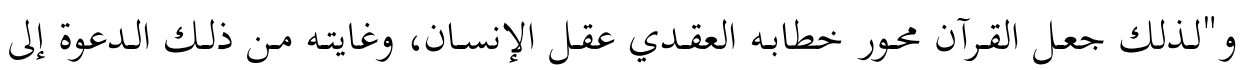

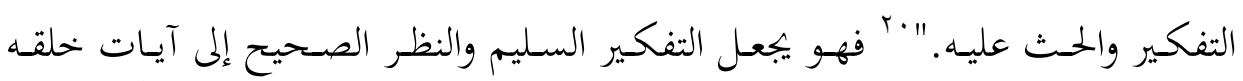

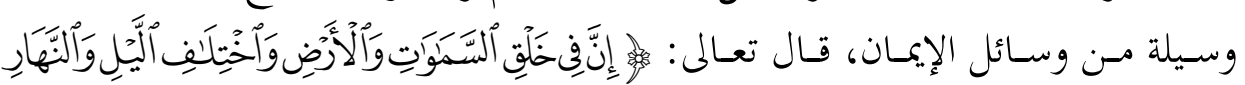

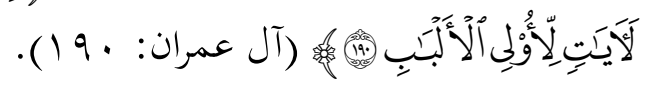

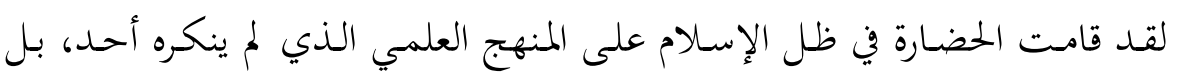

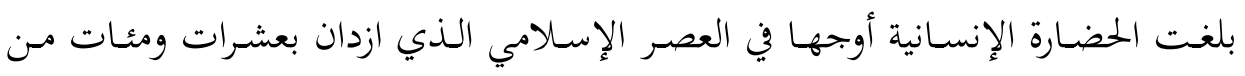

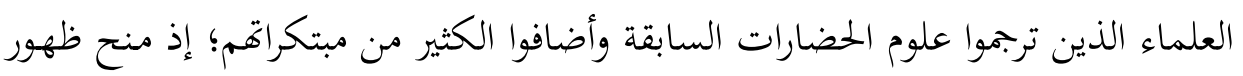
الإسلام الفكر العلمي دفعة قوية لكي ينفتح وينتشر ويزيد في معارف الإنسان ورفاهيته،

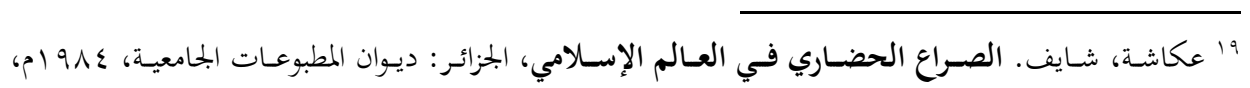
صإ ع-

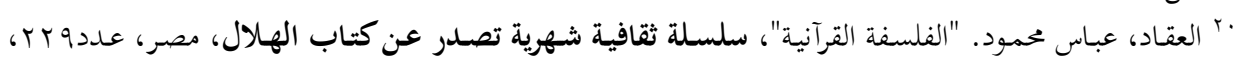




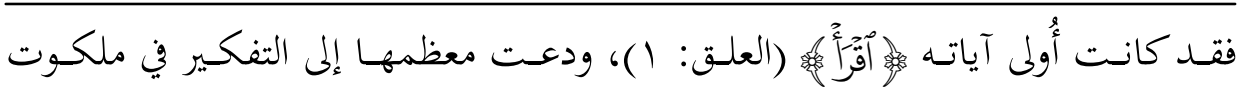
السماوات والأرض والكون والكائنات والنبات والحيوان، مُفِّرقةً بين الذين يعلمون والذين

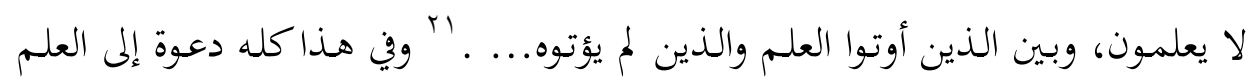
والتقدُّم والازدهار.

ولذلك حُقَّ لنـا قول إن القرآن الكريم هـو الذي يقود النـاس (بفضـل تعاليمـه) إلى

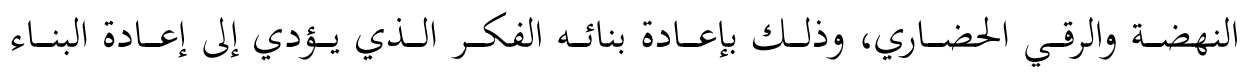

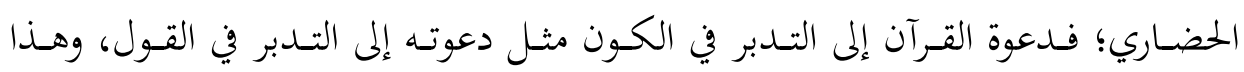

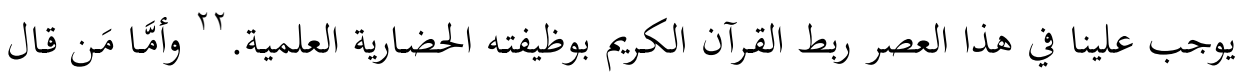

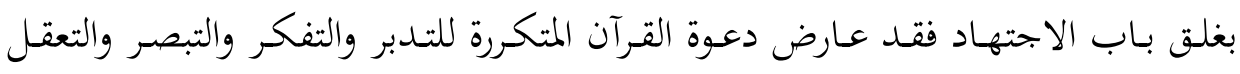

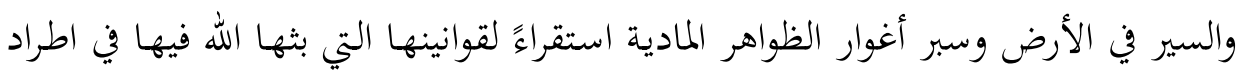
لا شذوذ.

وإن المتتبع لحال الجزيرة العربيـة، ومـا جـاء بـه الإسـلام والقرآن، وأتثره في إصـلاحها،

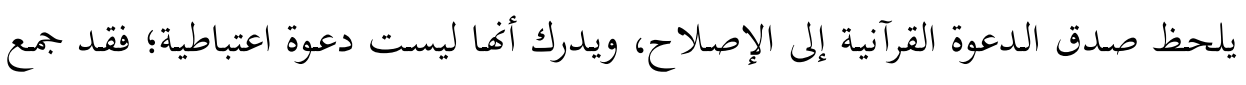

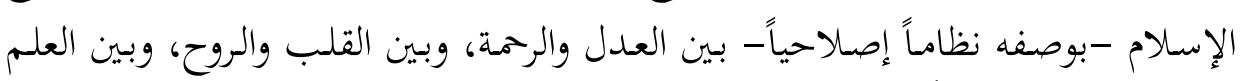

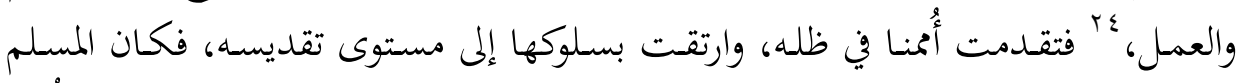

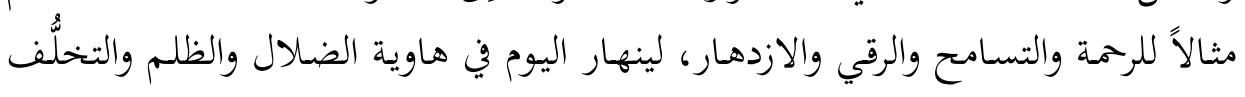
والدمار.

فعقيدة الإسلام إذن غير منفصلة عن الحياة، وهي إعداد للحياة، وتوجيه لها، ودفع إلى الغايات الكريمة والمقاصد الطيبة النافعة.

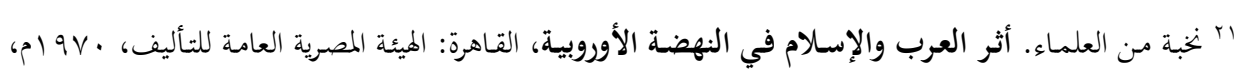

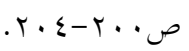

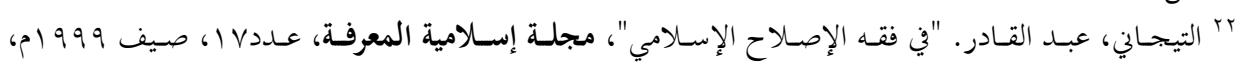

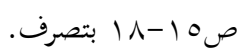
"r عرفـان، عبد الحميـد فتـاح. "الإطار الفكري العـام لنظرية المعرفة في القـرآن الكريع"، مجلـة إسـلامية المعرفـة،

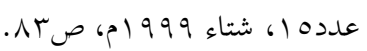

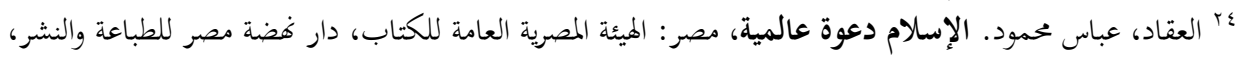




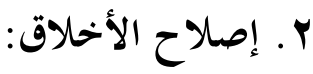

أكد القرآن الكريم محورية قضية الإنسان فيه، وأنه بصلاحه يصلح غيره، ويقيم دنياه

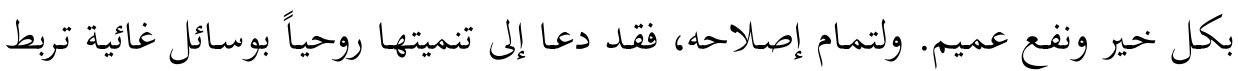

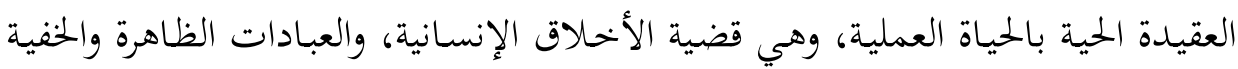

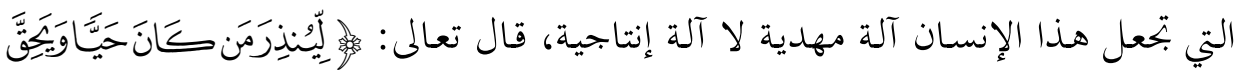

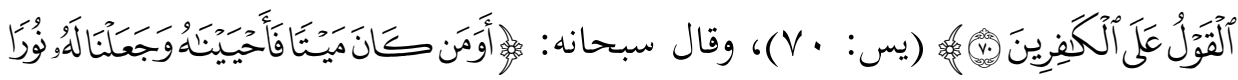

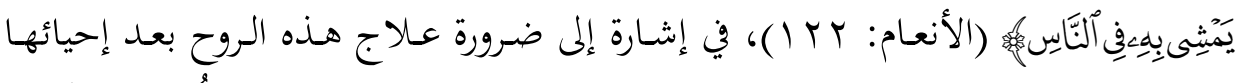

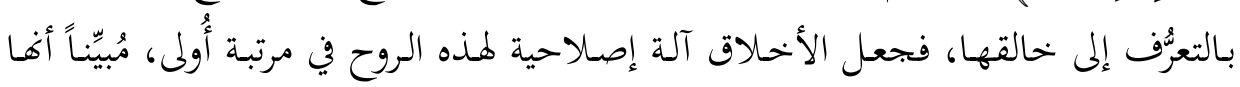

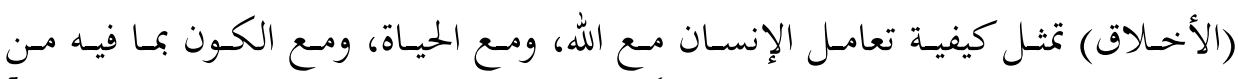

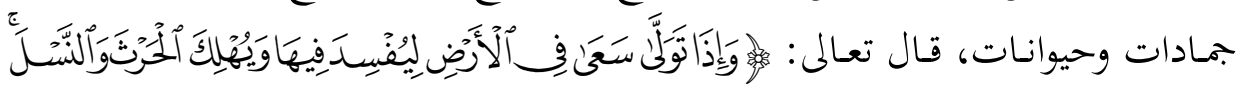

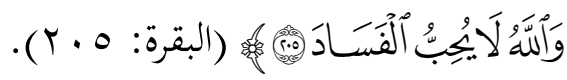

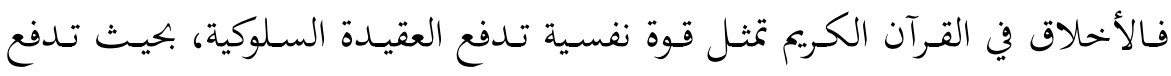

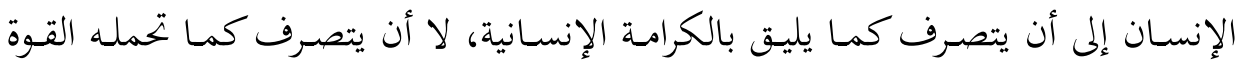

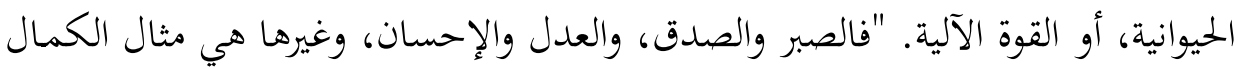

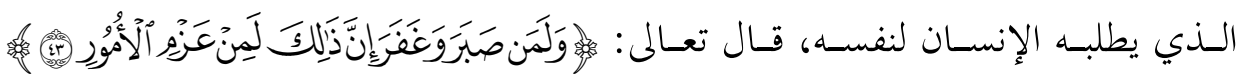

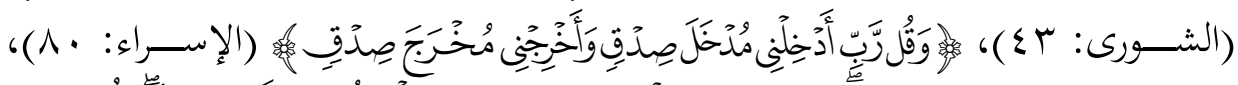

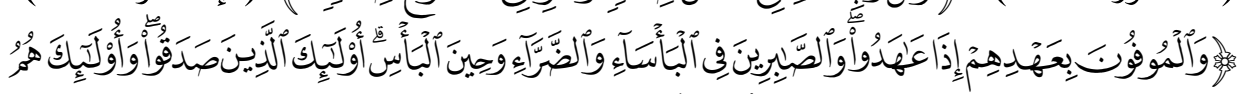

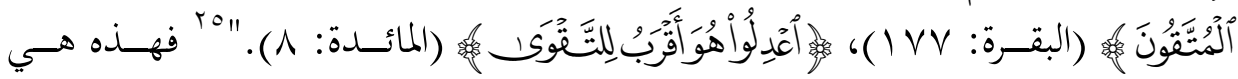

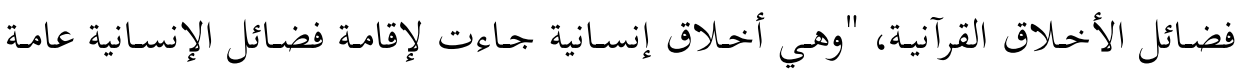

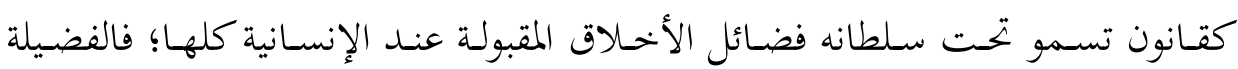

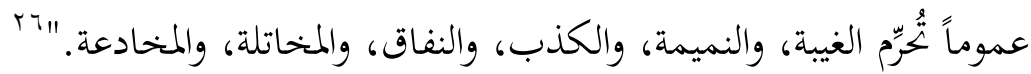

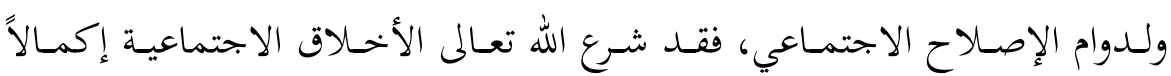

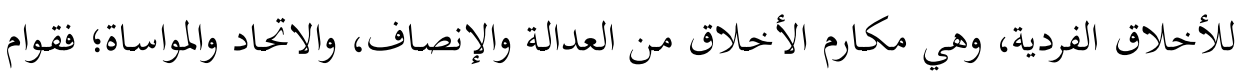

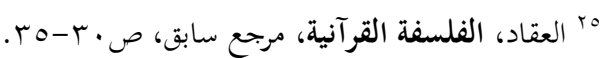

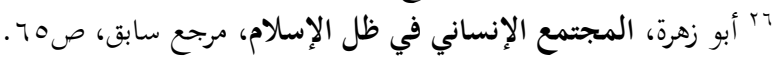


الإصلاح الجماعي هو الإصلاح الأخلاقي الذي يعود بـالنفع على المجتمع والإنسـانية

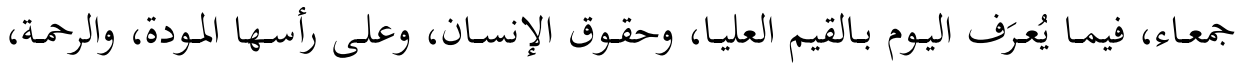

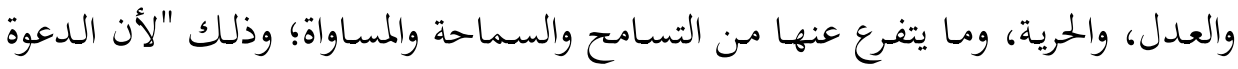

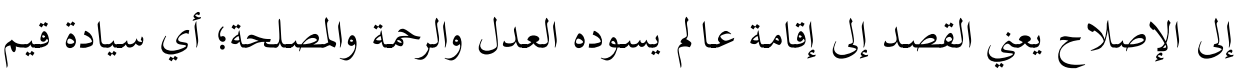

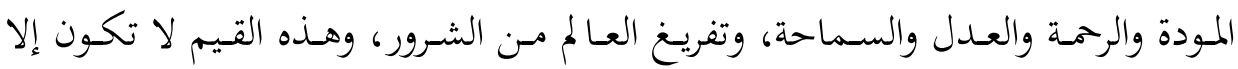

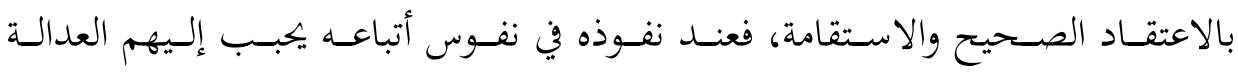

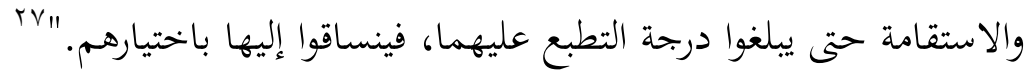

وقد نظرتُ في القيم الضرورية للإنسان فوجدات أهمها قيمتين، هما: العدل، واليسر والرحة؛ فبهما تتحقق مصالح الإنسان وتكتمل.

أ. العدل: هو قيمة عالية تتصدر كل القيم والثوابت التي يدعو إليها الدين عامـة

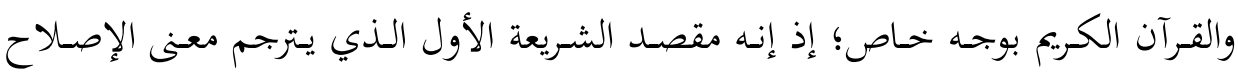

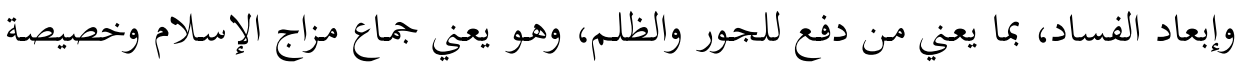

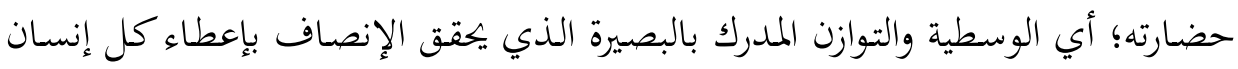

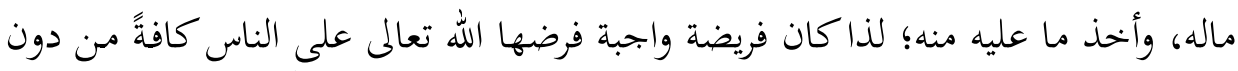

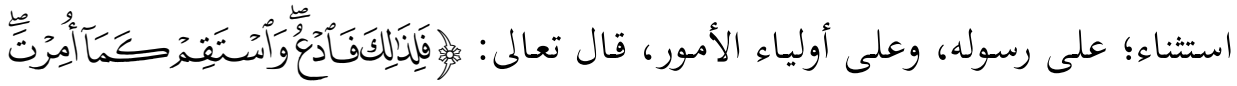

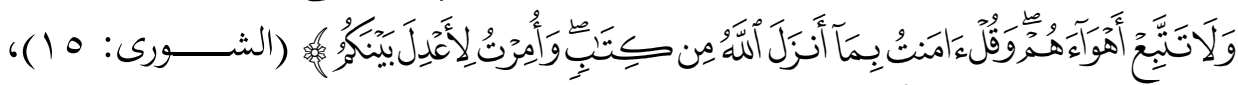
وقــال r^. (النساء: (م)

وأساس العدل في القرآن الكريم هو المساواة؛ "فالقرآن وإن أقرّ التفاوت بين النـاس

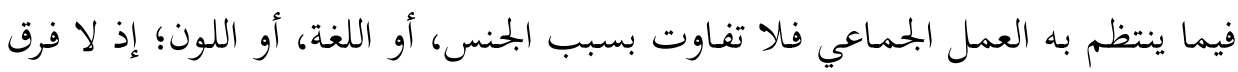

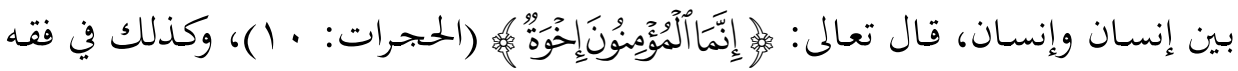

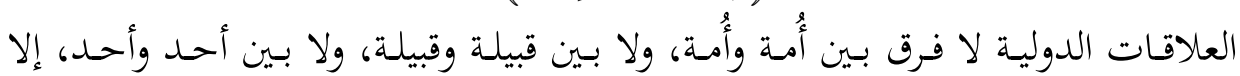

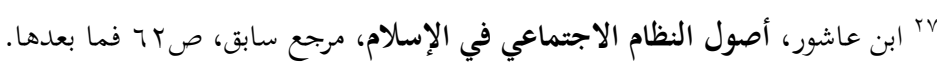

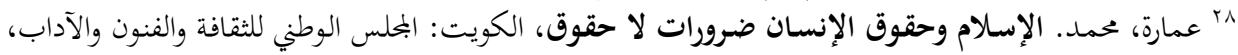




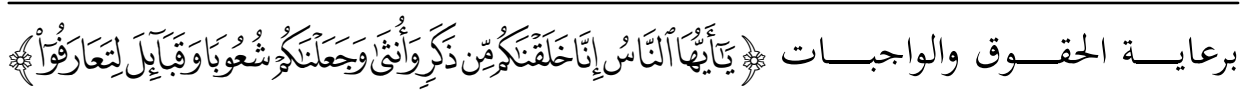

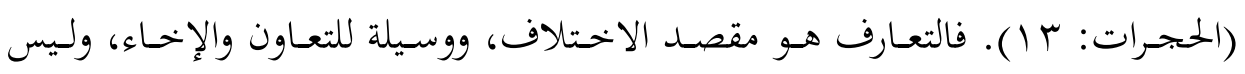

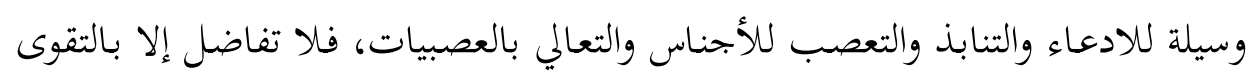

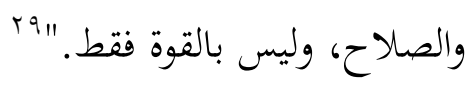

وأمَّا ما شاع على ألسن الناس من أن الإسلام دين سيف، وأن العلاقة بينه وبين

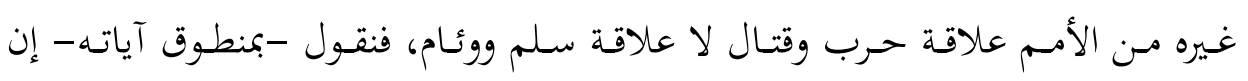

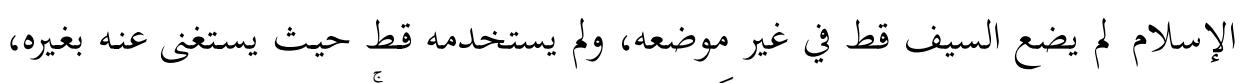

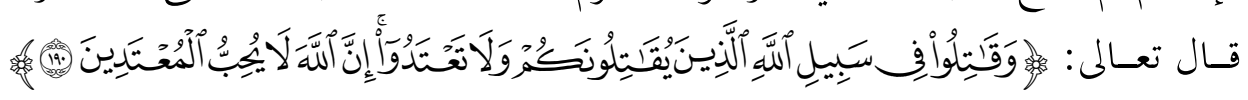

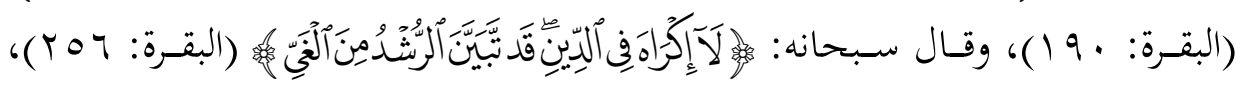

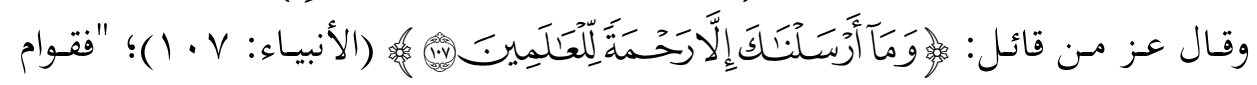

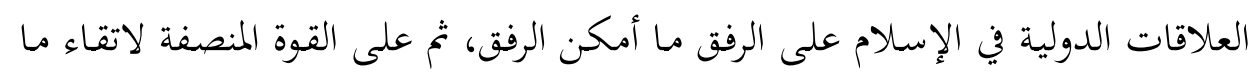

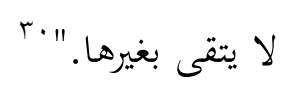

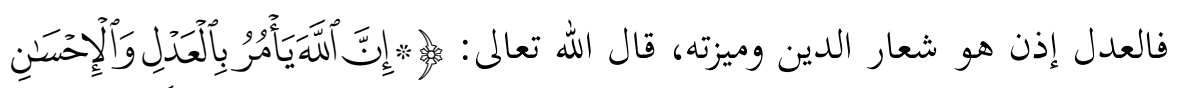

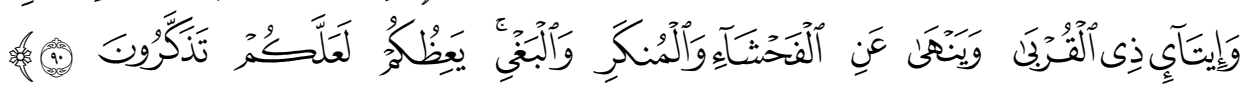

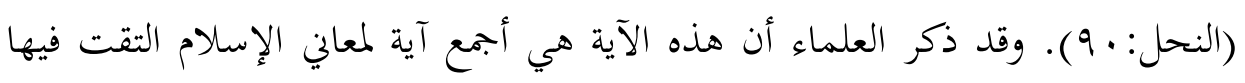
كل خواصه.

ب. اليسر والرحمة: اليسر والرحمة من أوضح سمات الشريعة الإسلامية، بل عنواها

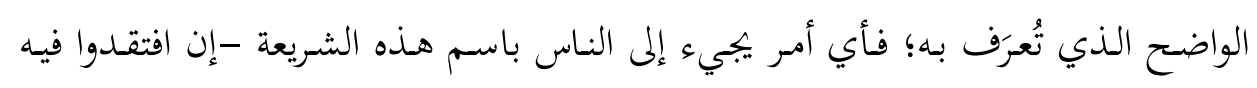

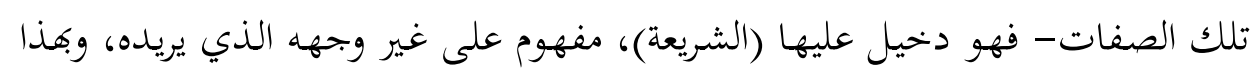

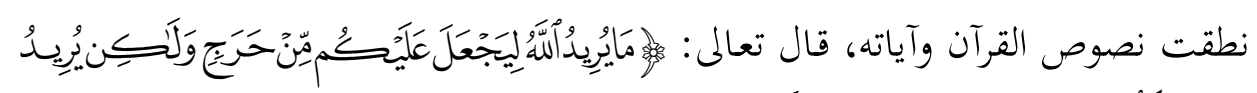

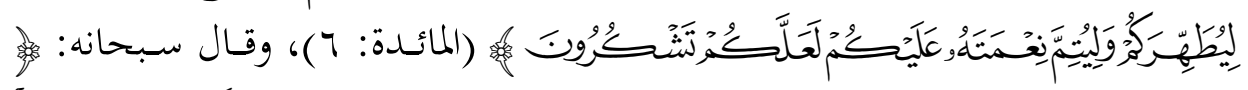

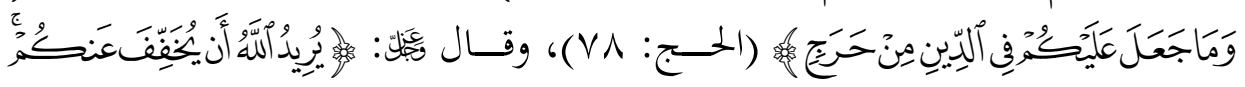

$$
\begin{aligned}
& \text { ra }
\end{aligned}
$$

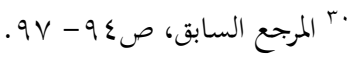

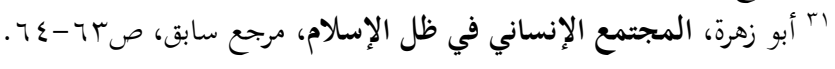




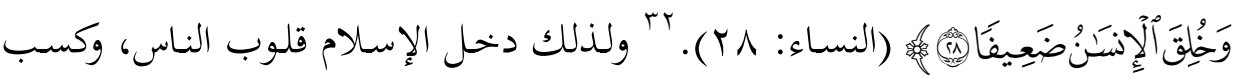

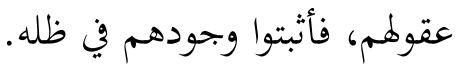

\section{ثالثاً: مقصد إصلاح العالم بتشريع العبادات الصحيحة}

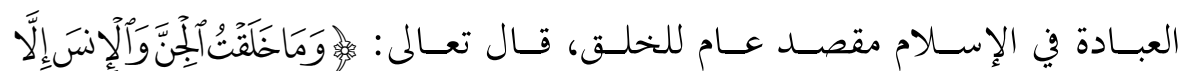

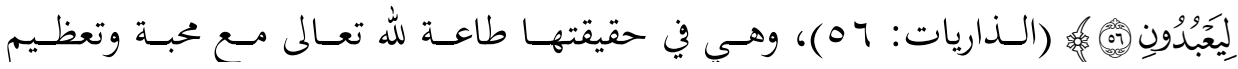

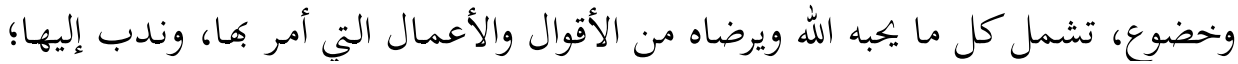

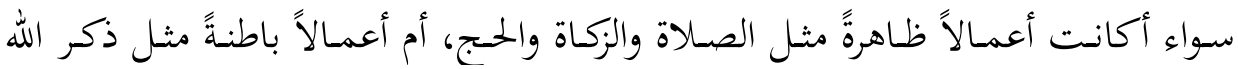

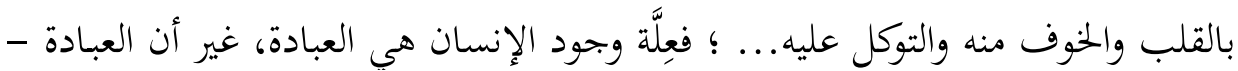

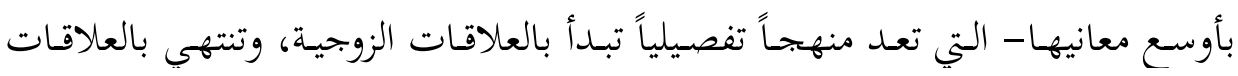

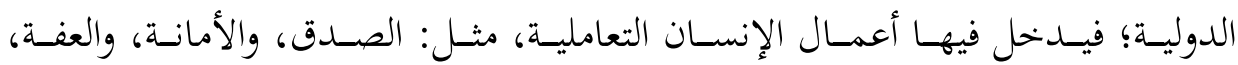

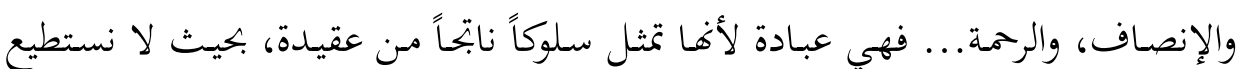

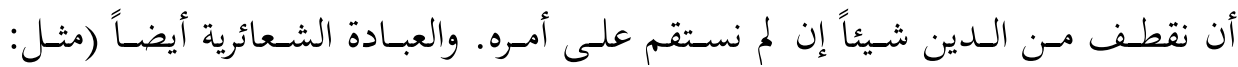

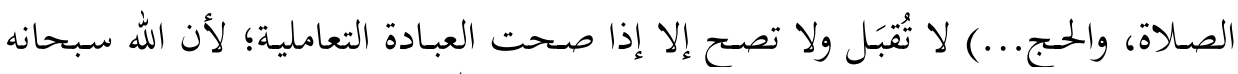

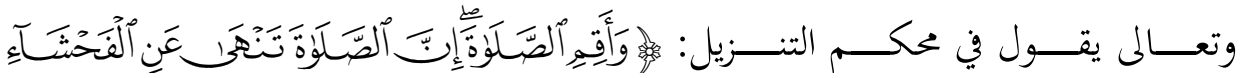

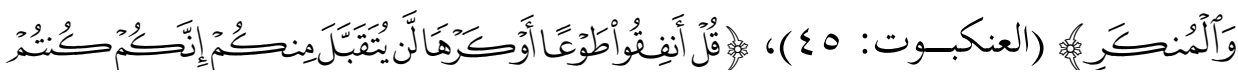

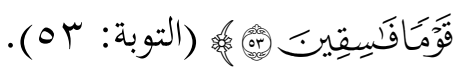

ومقصـود العبـادة لا يتحقـق إلا إذا أدَّى الإنسـان وظيفتـه الاستخحلافية التي تتحقـق

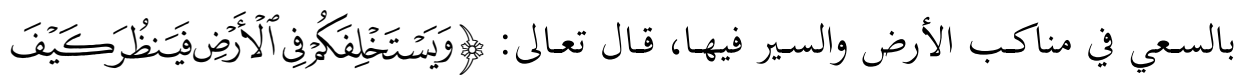

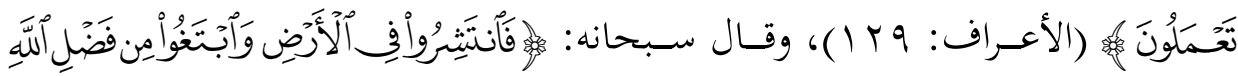

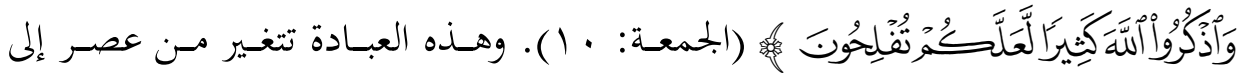

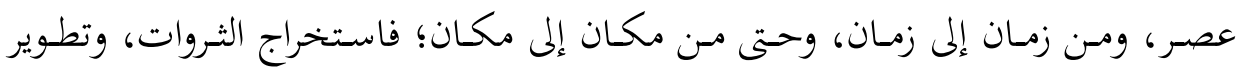

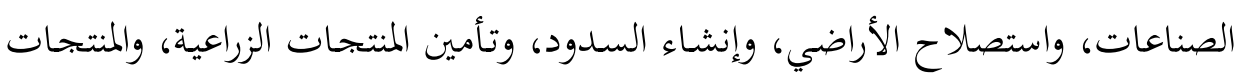

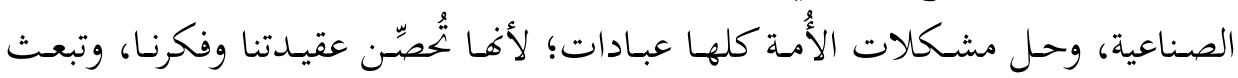

rr الخطيب، عبد الكريم. التعريف بالإسلام في مواجهة العصر الحديث وتحدياته، بيروت: دار المعرفة، وV0 (1م، 


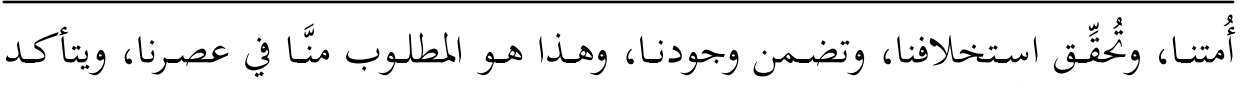

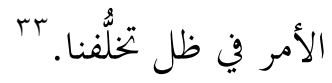

وتأسيساً على ذلك، فإن معنى العبادة في الإسلام يتضمن الدين والحياة من جهة، وكيان الإنسان (ظاهره، وباطنه) من جهة أخرى، ولعل ذلك هو ما دفع العلماء المحققين

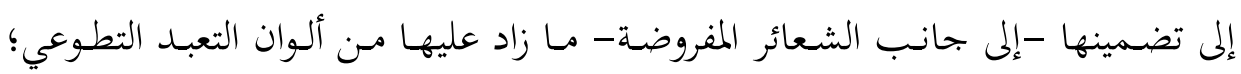
من: ذكر، وتلاوة، واستغفار، ومن أخلاق وفضائل إنسانية جامعة، مثل: الصدق، وأداء

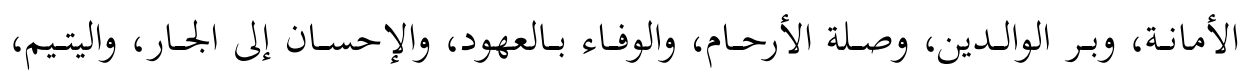

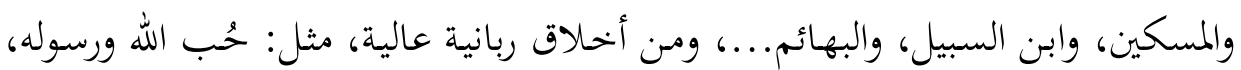

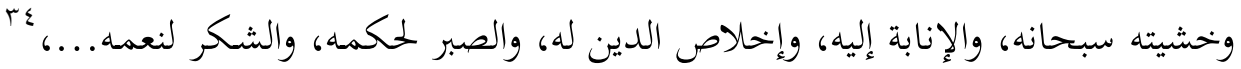
ومـن عبـادات كونيـة حضـارية، مثل : البنـاء، والتعمـير، والاكتشـاف، والتصـنيع، وإعـداد

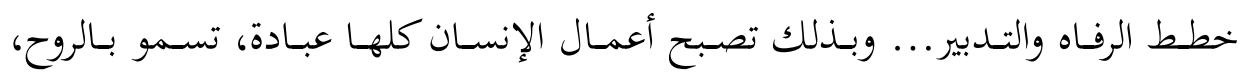

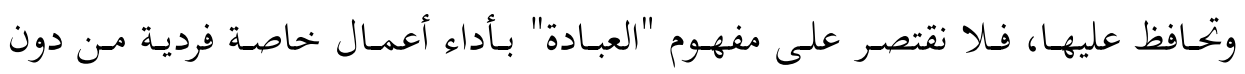

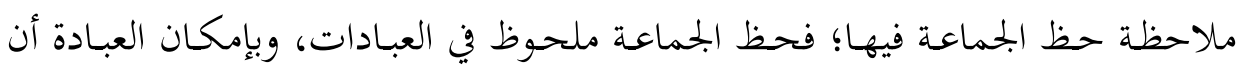
تبني أُماً في ظل التوسع الروحي.

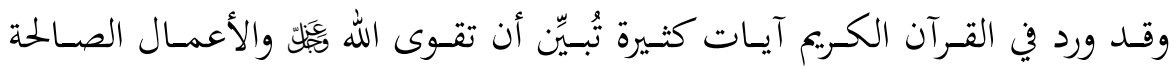

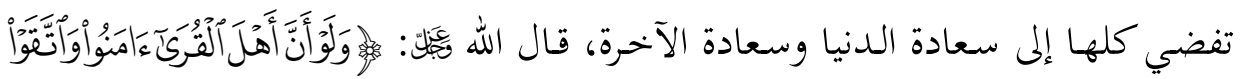

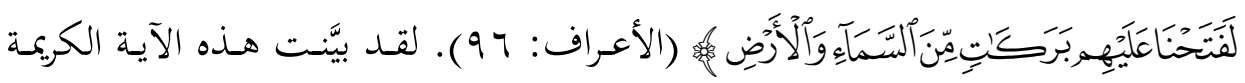
الأثر المترتب على العبادة في حياة المسلم؛ فمَن اتقى الله هيَّلَّل وآمن به، فإن الله تعالى يثيبه

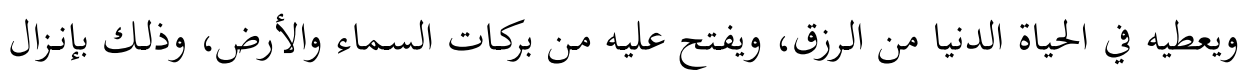

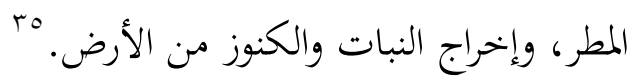

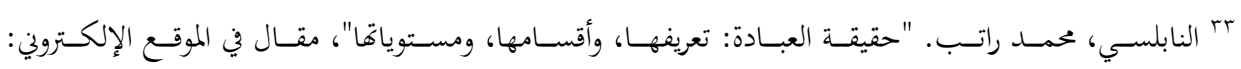

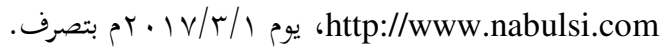

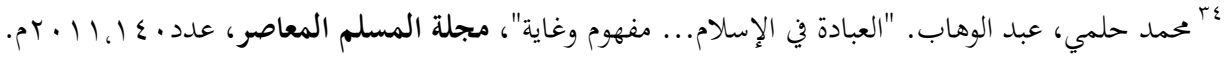

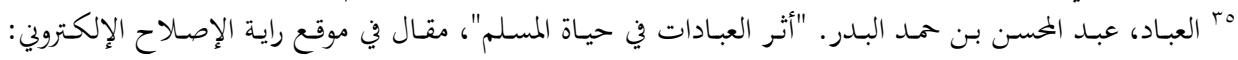
http://rayatalislam.com 


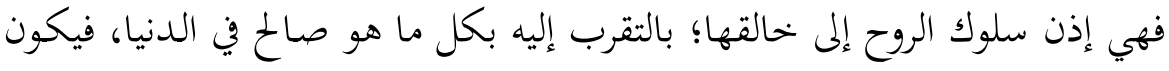

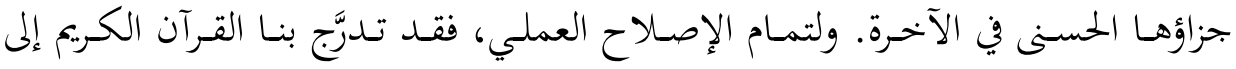

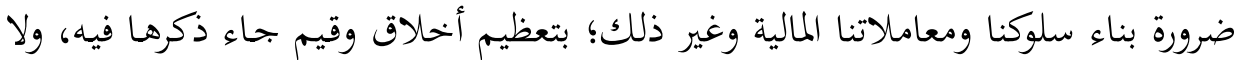

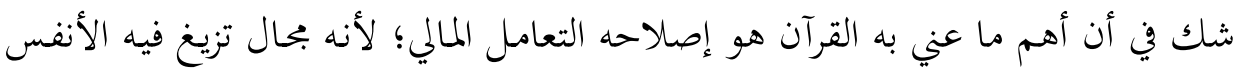

\section{رابعاً: مقصد إصلاح العالم بإصلاح المعاملات}

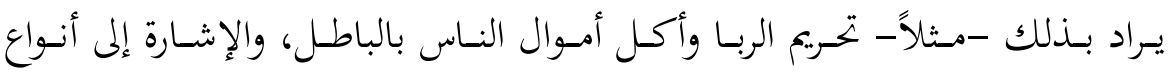

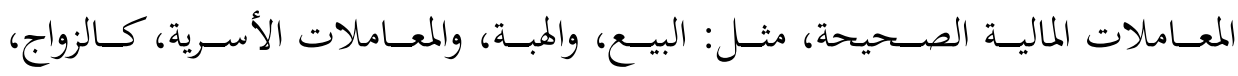

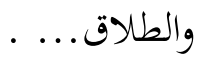

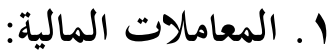

نبَّه القرآن الكريم لعديد المعاملات المالية الصحيحة؛ نظراً إلى ضرورتا في إقامة

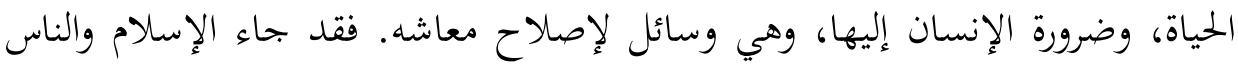

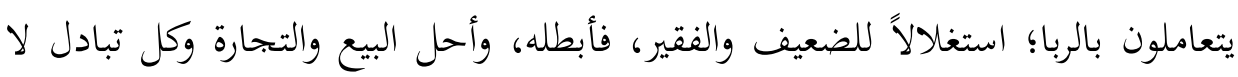

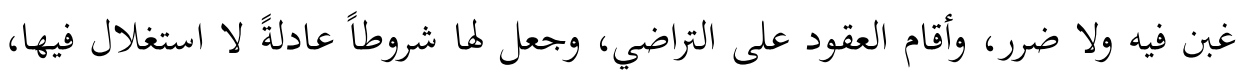

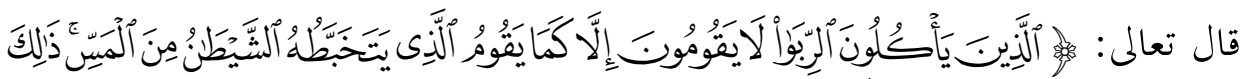

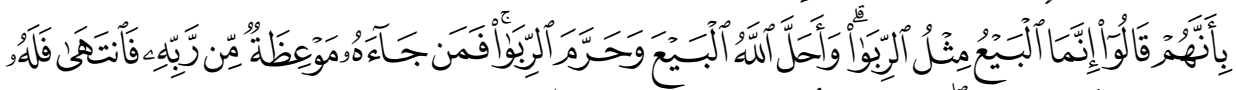

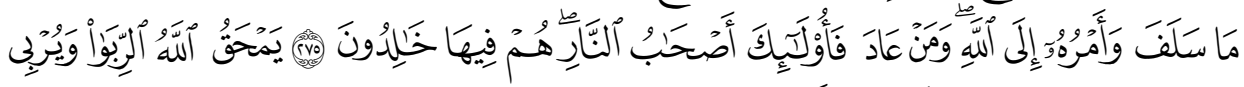

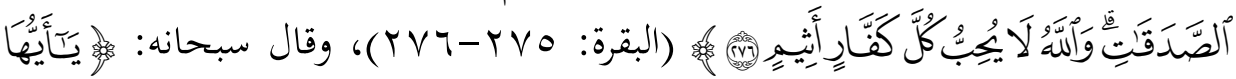

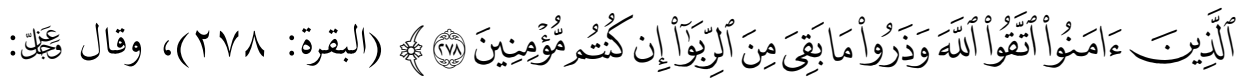

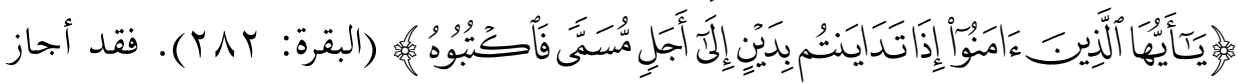

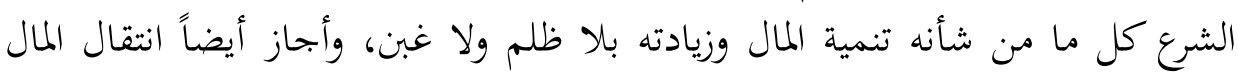

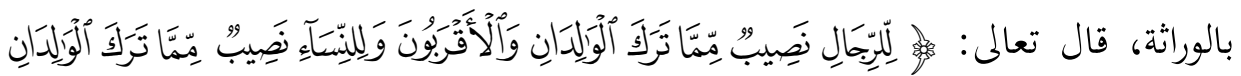

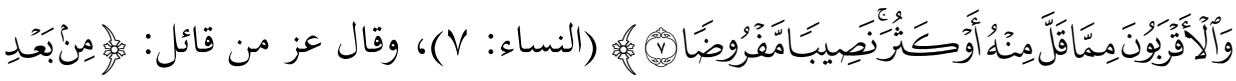




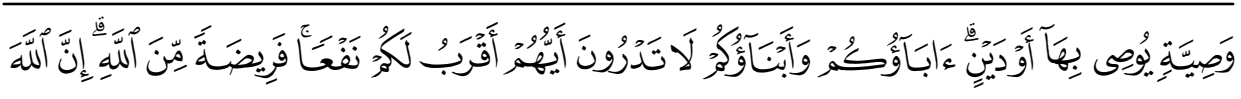

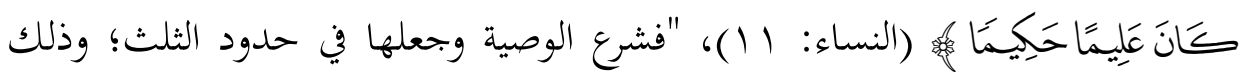

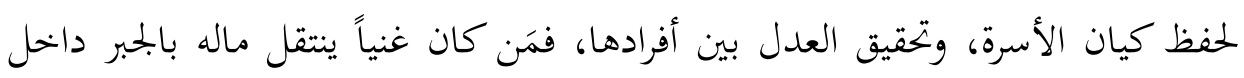
الأسرة في دائرة الثلثين، وقد كان الإسلام في ذلك وسطاً بين الذين قطعوا أوصال الأسرة

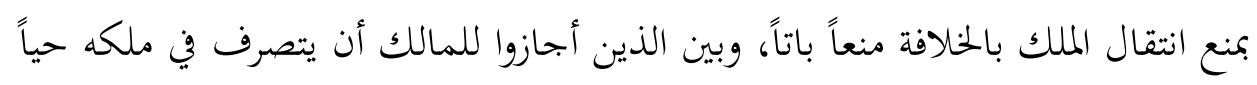

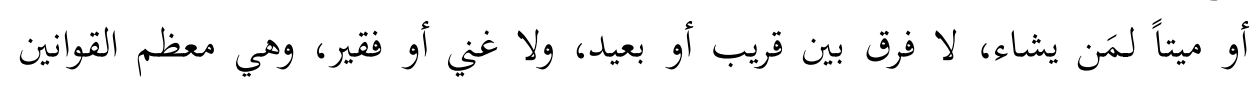

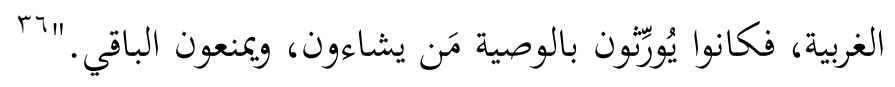

وبهذا تأصلت في القرآن الكريم أسس النظام المالي الإسلامي الذي يقوم على النهي

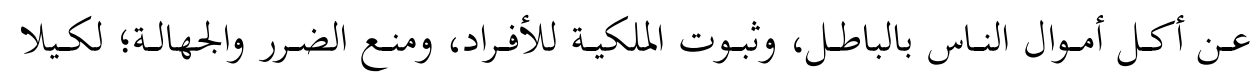

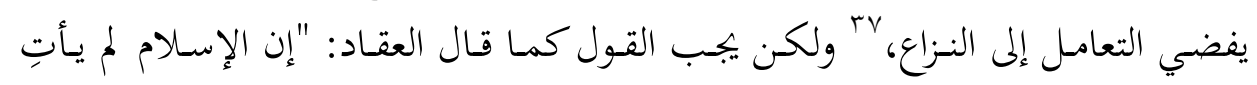

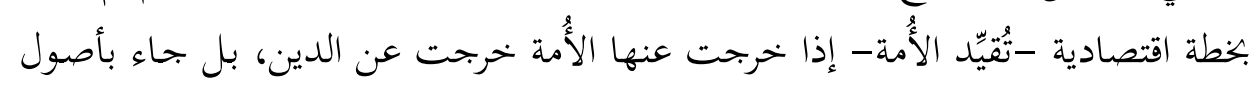

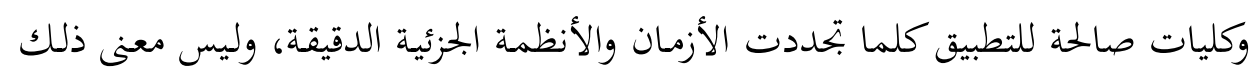
أن الإسلام ينفض يديه من مهمة الإصلاح الاجتماعي في زمن من الأزمنة، ولكن معناه

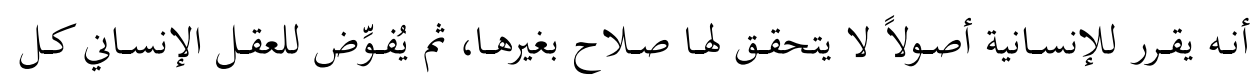

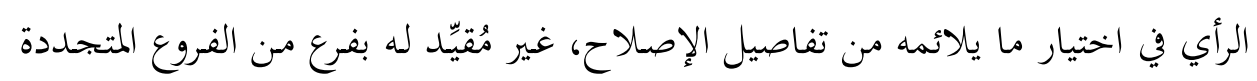

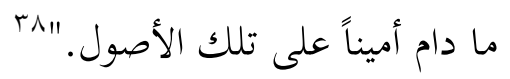

فموقف الإسلام الفريد من المال ينسجم مع الحقيقة التي يقوم عليها بناء هذا الدين

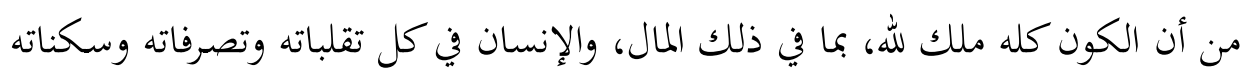

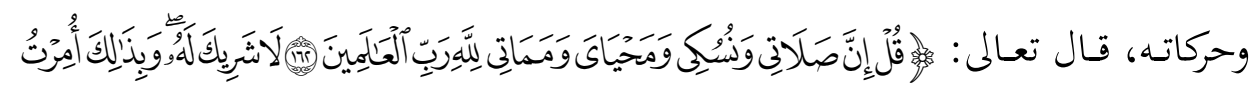

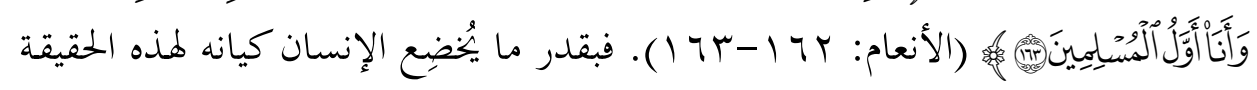

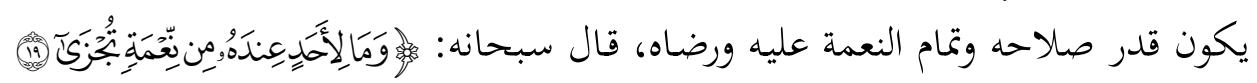

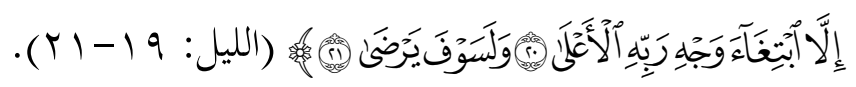

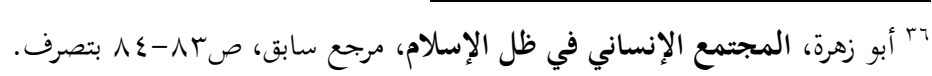

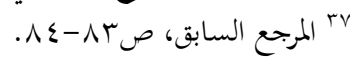

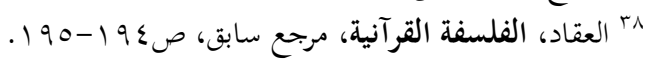




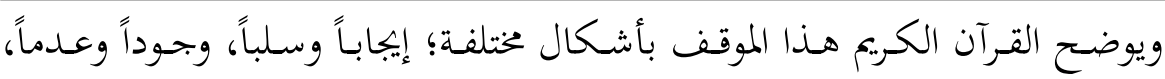

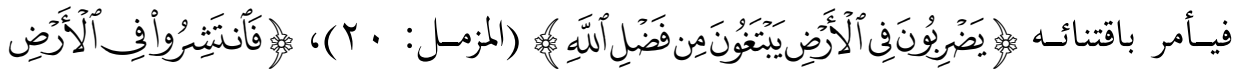

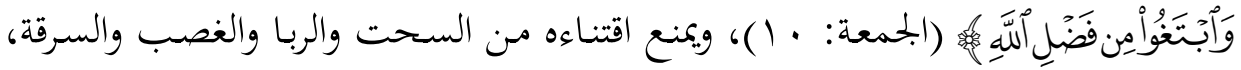

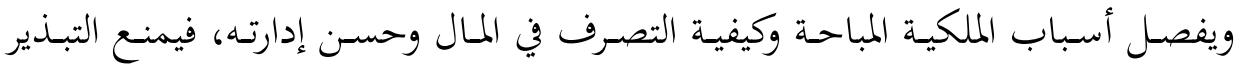

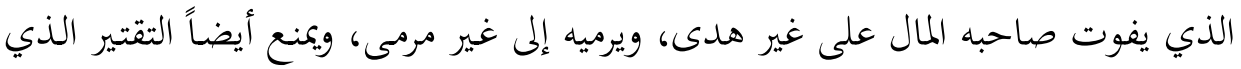

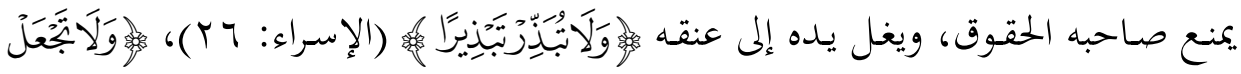

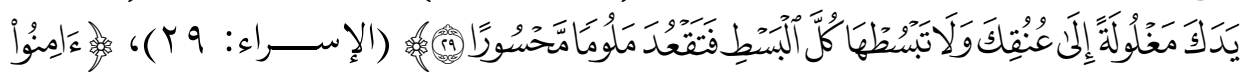

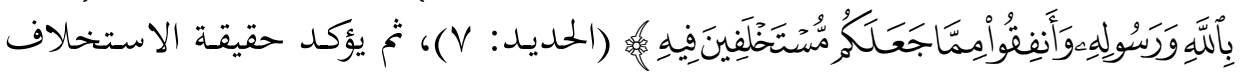

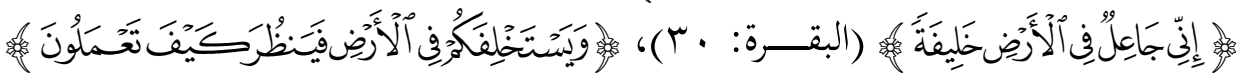

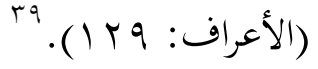

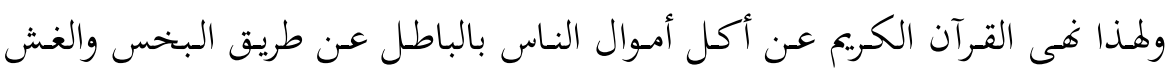

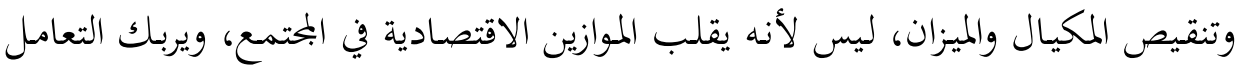

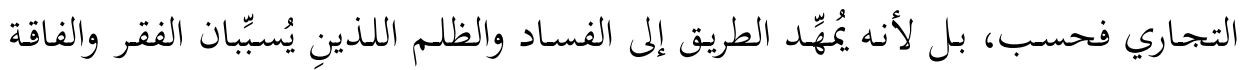

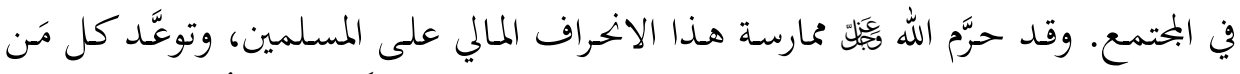

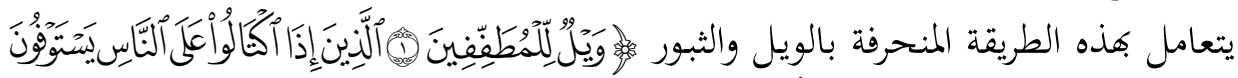

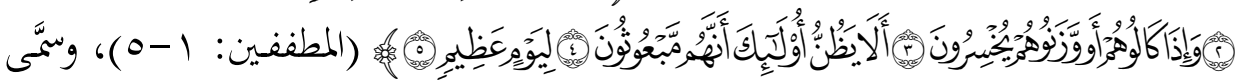

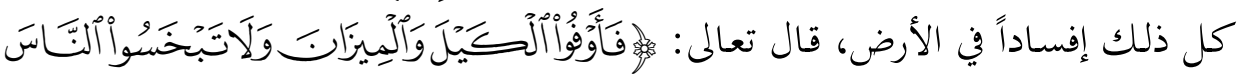

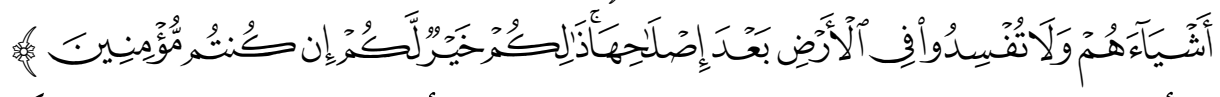

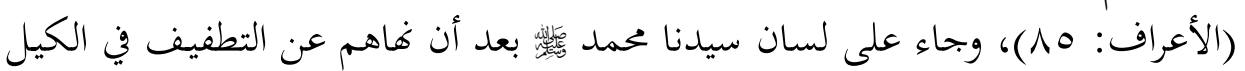

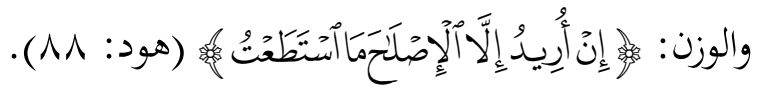

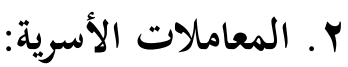

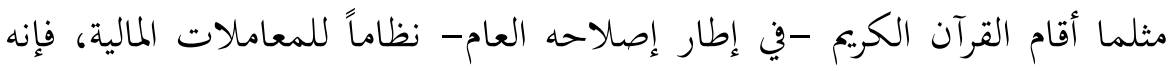

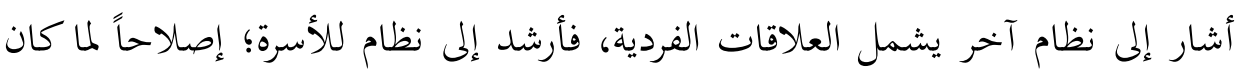
هَr ابن بية، عبـد الله. "المعاملات والمقاصد"، بحـث مقـدم للدورة الثامنة عشرة للمجلس الأوروبي للإفتاء، بـاريس،

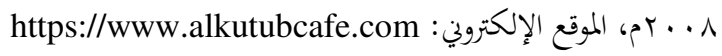




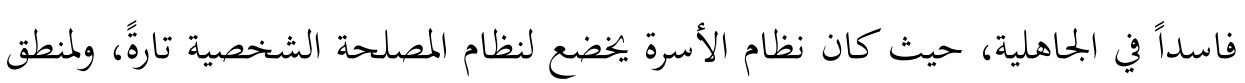

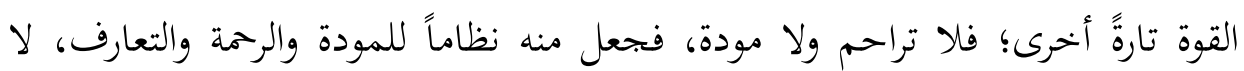

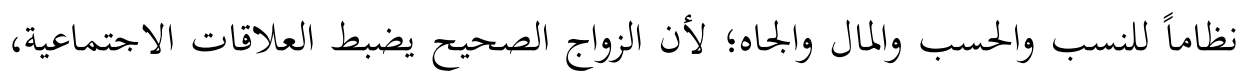

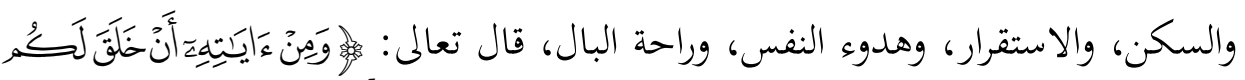

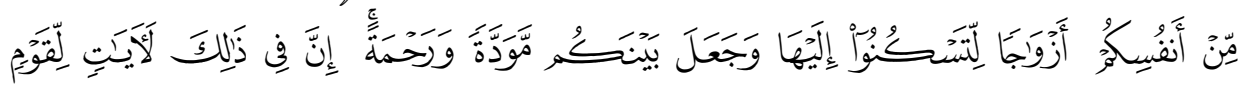

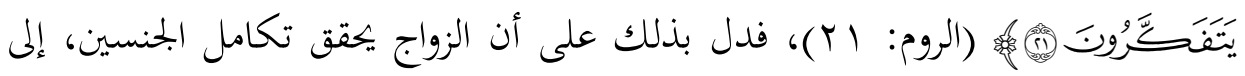

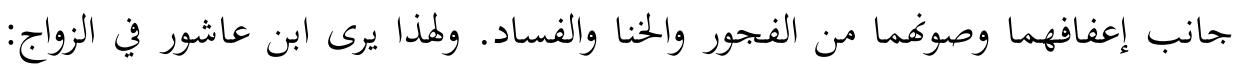

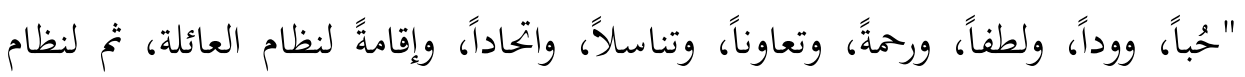

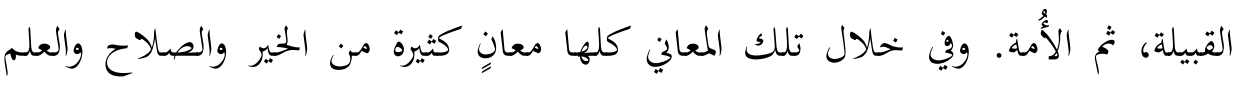

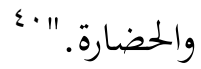

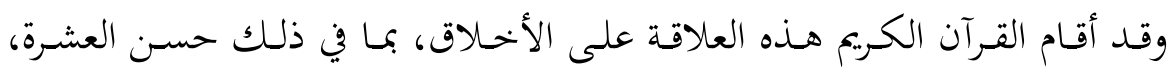

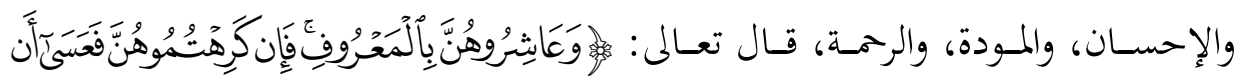

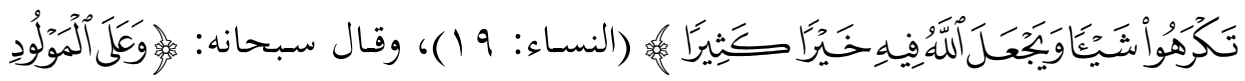

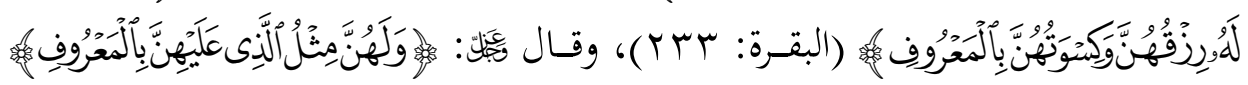

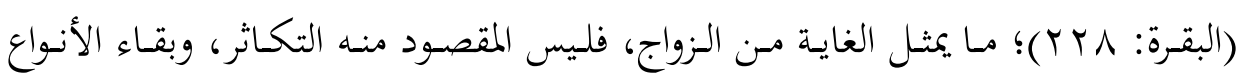

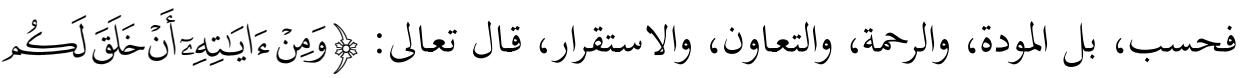

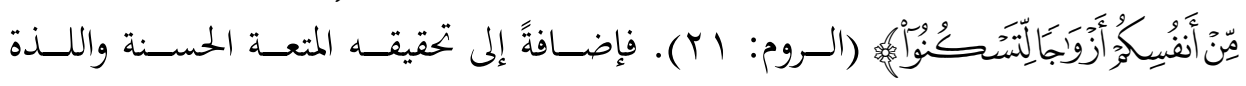

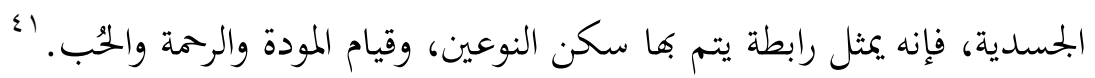

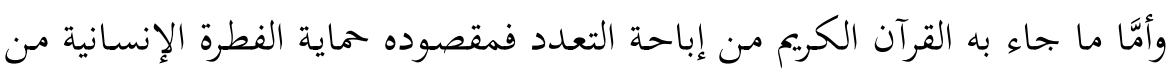

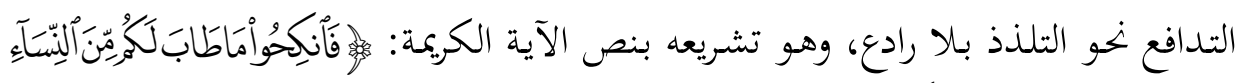

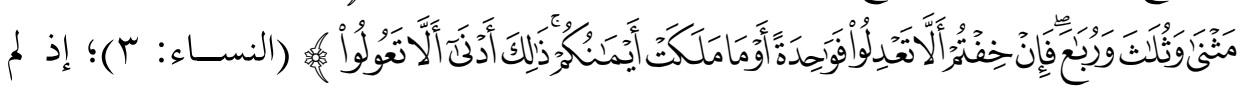

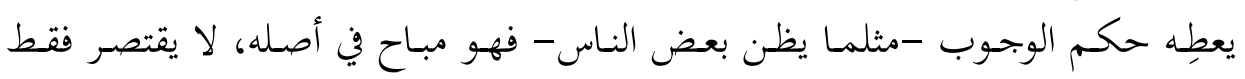

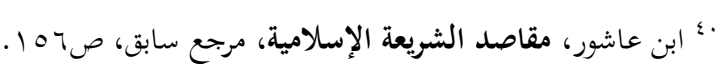

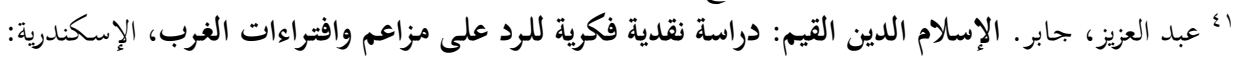

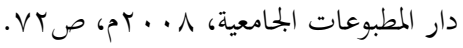


على التلذذ الحيواني، والتنقل بين الزوجات، كما ينتقل الخليـل في الخليلات، وإنما هو

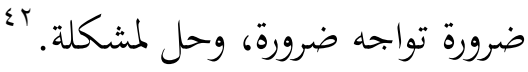

وبالمقابـل، فقــ أشـار القـرآن الكـيم إلى طرائق انحـلال هـذه الرابطـة بعـد اسـتحالة

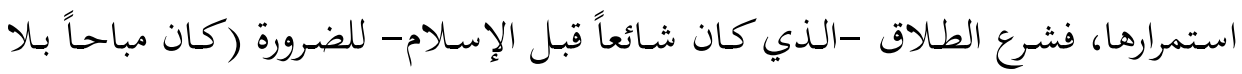

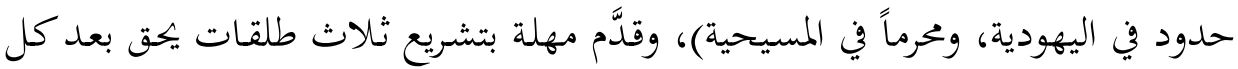

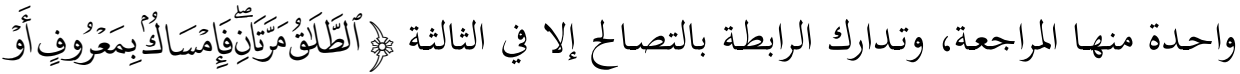

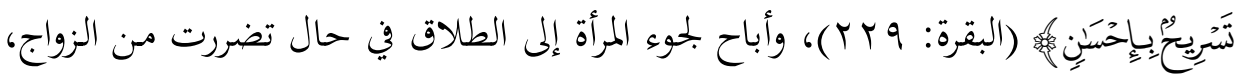

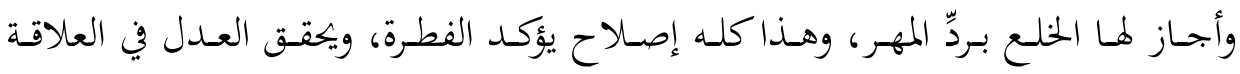

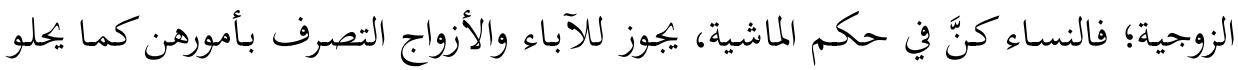

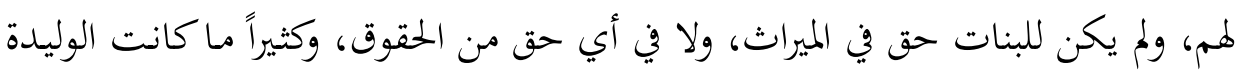

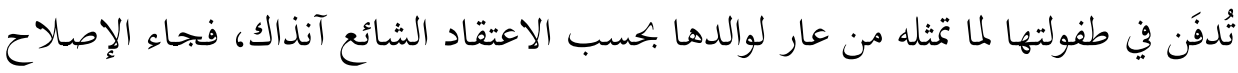

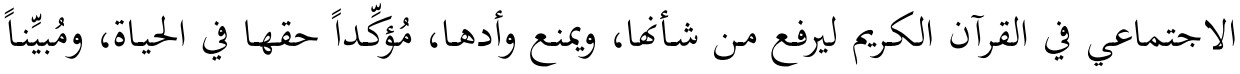

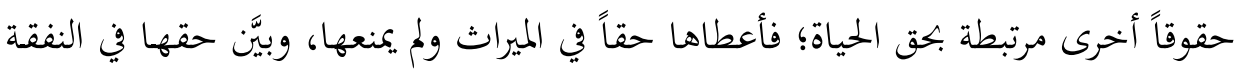

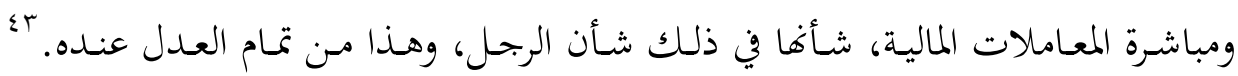
وبذلك ساوى القرآن الكريم بين المرأة والرجل في جميع الحقوق والواجبات. أمَّا ما آل إليه

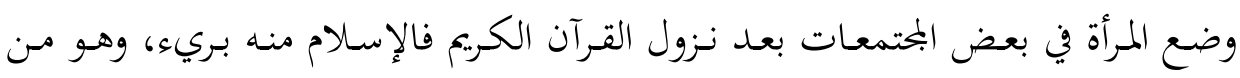

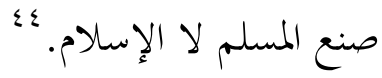

وذكر أحكام الأسرة في القرآن الكريم له حِكـم عـدَّة، منها: عـدم ارتيـاب أحسد في

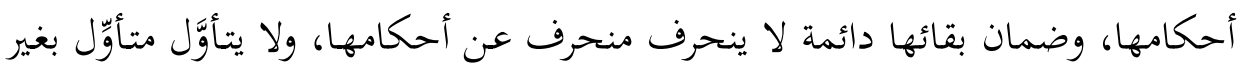

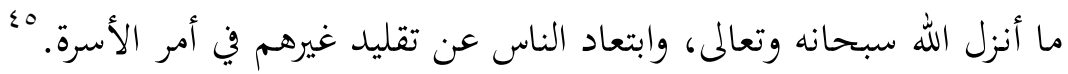

rأ مسلم، مصطفى، ونخبة من علماء التفسير وعلوم القرآن. التفسير الموضوعي لسور القرآن الكريم، الشارقة:

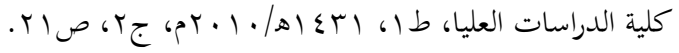

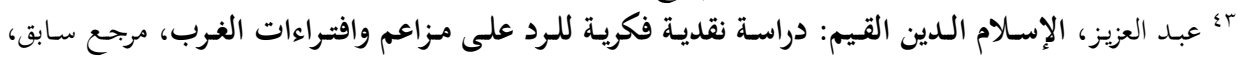

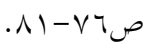

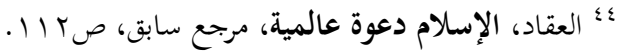

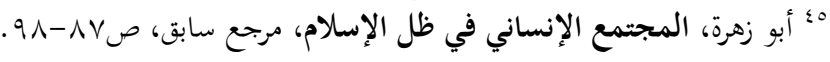




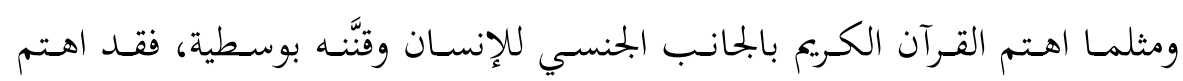

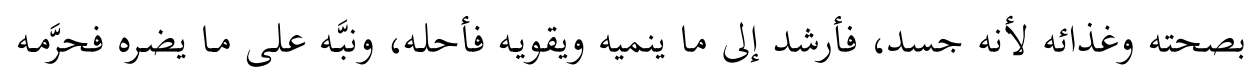
حتى يتميز عن غيره من المخلوقات.

\section{خامساً: مقصد إصلاح العالم بإصلاح العادات}

يكون ذلك بالتنبيه على أنواع المطعومات والملبوسات، والنهي عن تناول الخبائث،

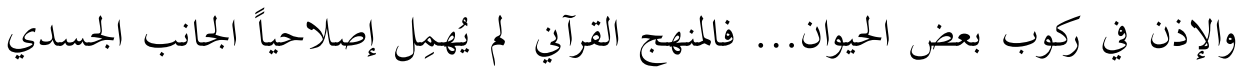

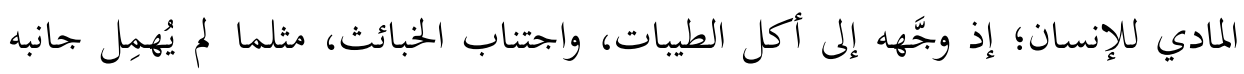

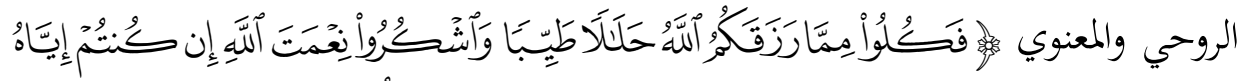

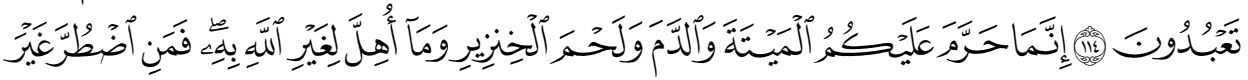

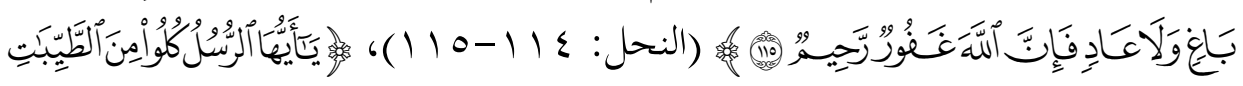

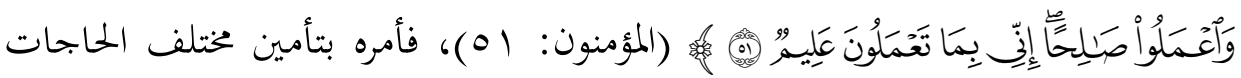

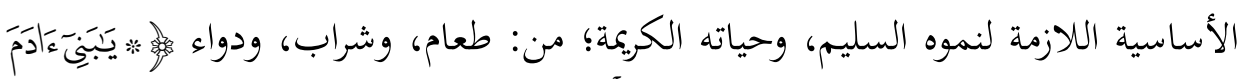

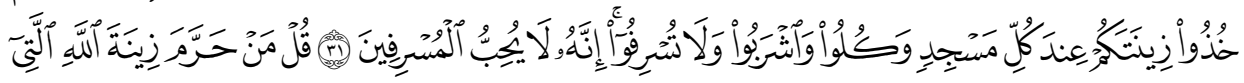

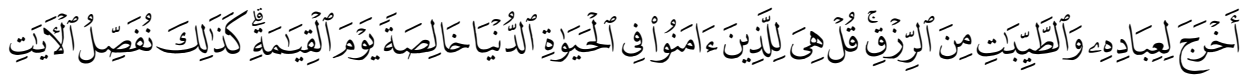

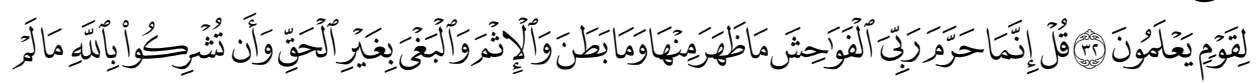

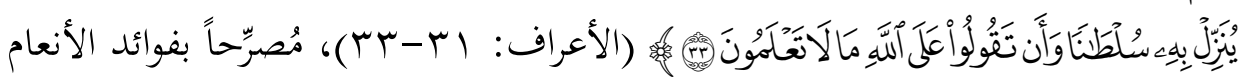

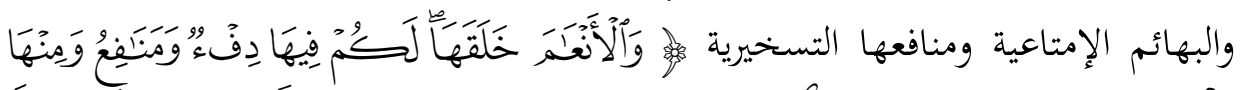

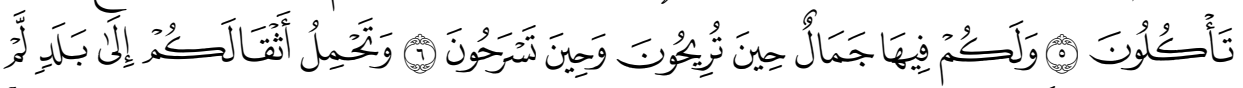

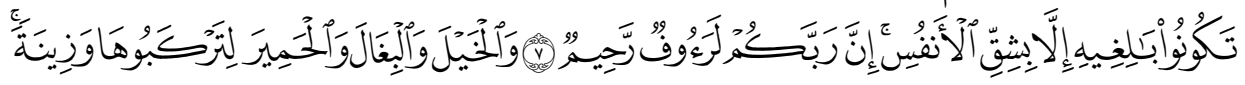

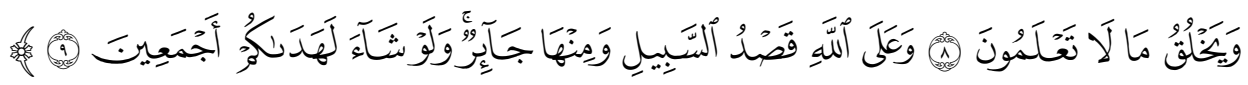

$$
\text { (النحل: (9-0) }
$$

وومَّا يـدل على قصد إشباع حاجـة الإنسـان الجمالية، إلى جانب حاجتـه البيولوجية

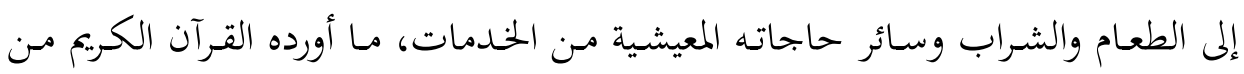


مشاهد الجمال والتزين والتمتع بالطيبات، في إشارة إلى ضرورة تقويم السلوك وضبطه بما

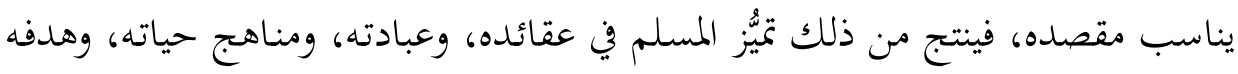

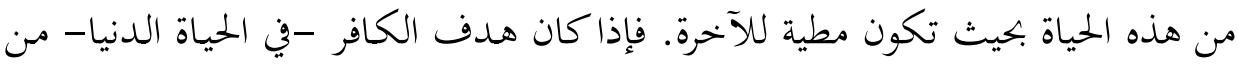

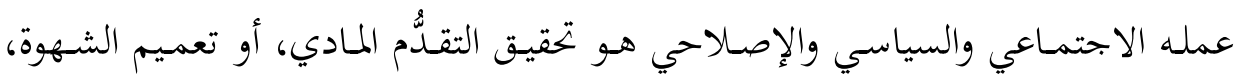
فإن الهدف العام للمسلم في عمله العام هو إقامة الدين لتحقيق مصالحه؛ ما يفضي إلى

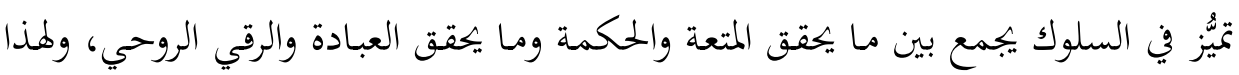

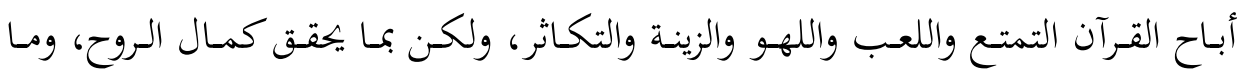

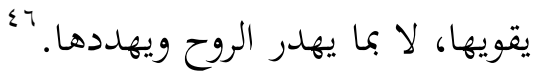

فالإنسان في نظر القرآن روح وجسد، وكما شرع ما ينمي الروح ويكملها شرع ما

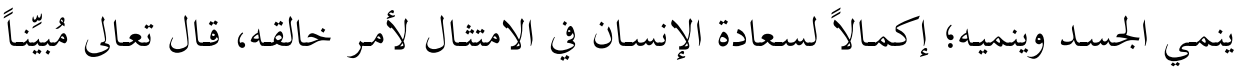

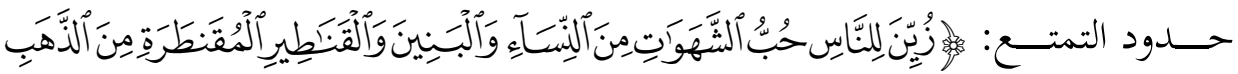

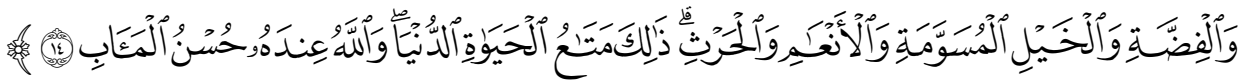

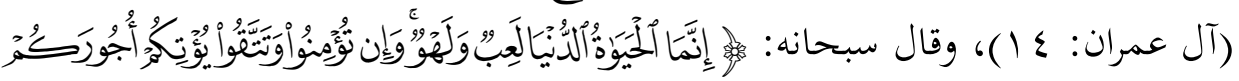

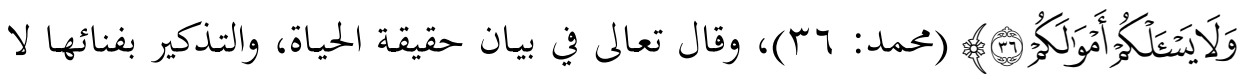
بة : محال

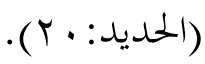

وقد أرشد القرآن الكريم المسلم إلى ضرورة التوسط في التمتع واللعب واللهو؛ لكيلا

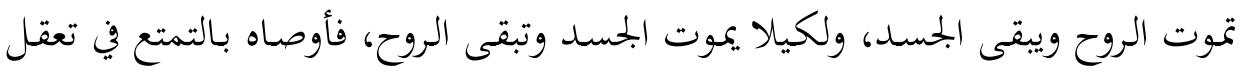

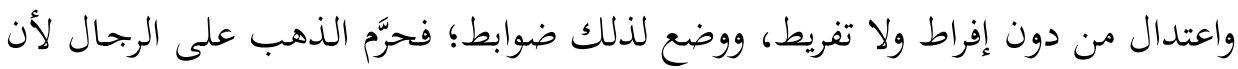

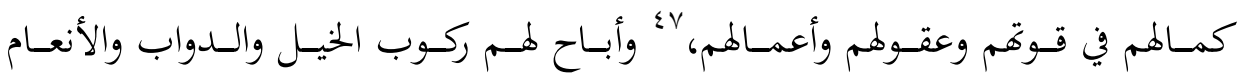

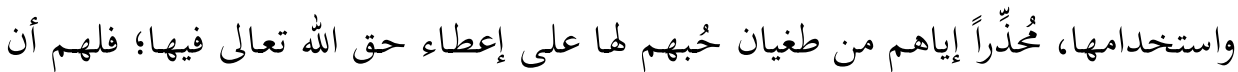

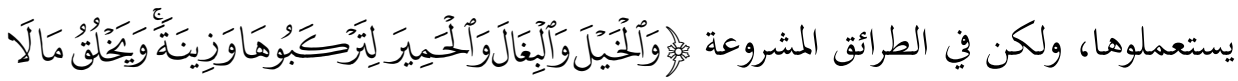

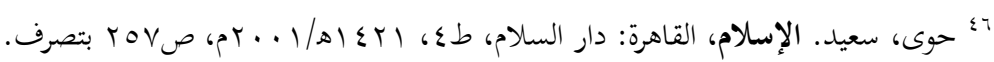

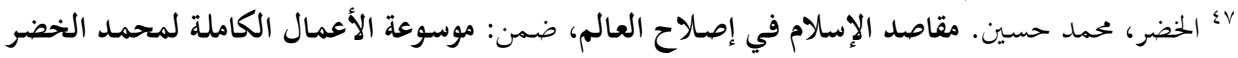

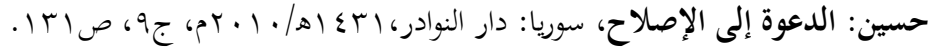




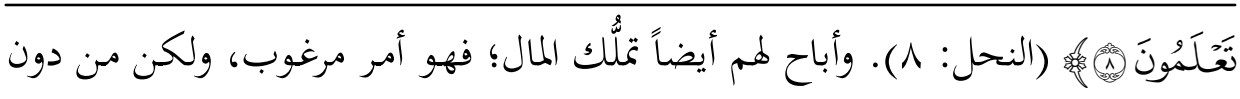

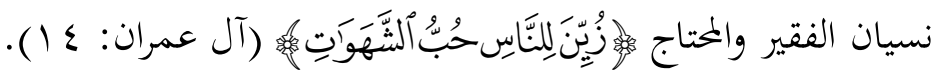

وخلاصة ذلك أن المسلم يحب المال بوصفه وسيلةً لحفظ كرامته عن ذل السؤال،

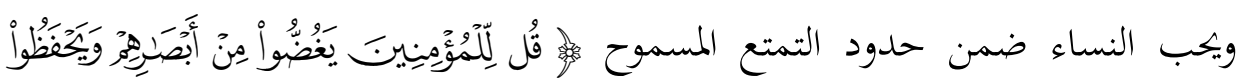

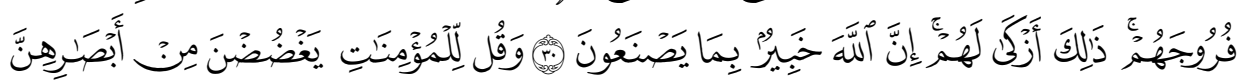

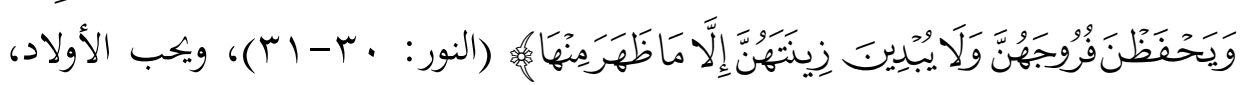

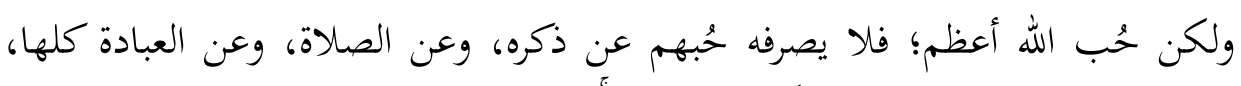

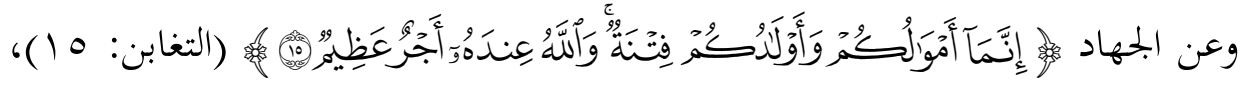

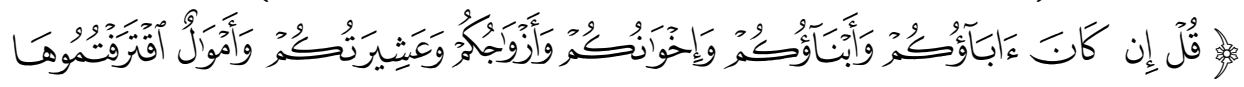

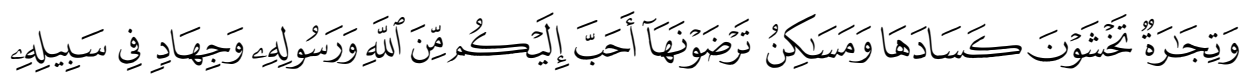

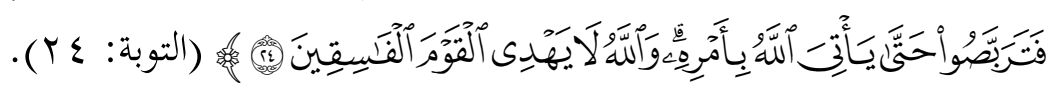

والحقيقـة أن الخيـل والأنعـام والحـرث والسيارات الفـاخرة وكل مـا يُركَب هـو سـبيل

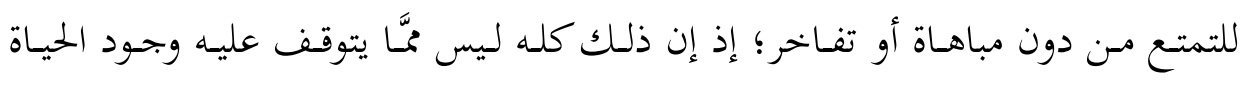
وقيامها واستمرارها، وإنما هو تكميلات وتحسينات، فلم يُكثِر القرآن الكريم من ذكرها؛ لأن الاهتمام بها يقلب الفروع عن أصولها، ويميت القلب وروحها. أمَّا التمتع بالطعام والشراب فقد أباحه القرآن الكريم بما يحقق وجوده بوصفه إنساناً متميزاً عن الحيوان؛ فلا لإن

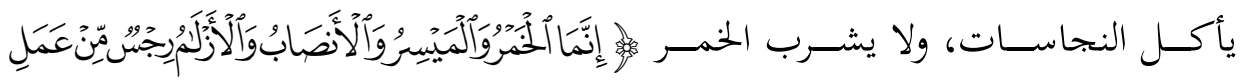

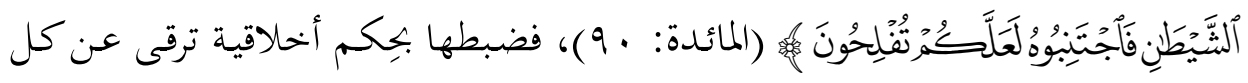
حكمة غذائية.

وغاية القرآن الكريم من هذا كله هي جعل الإنسان محور الحضارة التي يريد إنشاءها؛

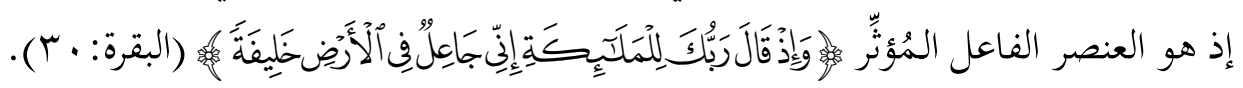

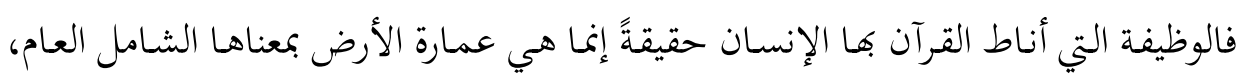
الـتي تشـتمل علـى إقامـة بحتمـع إنسـاني سـليم، وتشـييد حضــارة إنسـانية شــاملة. 


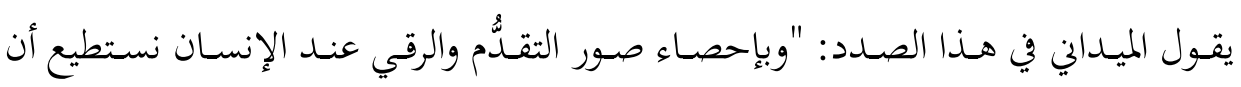
نرجعها إلى الأصناف الثلاثة التالية:

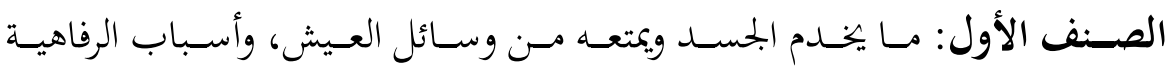

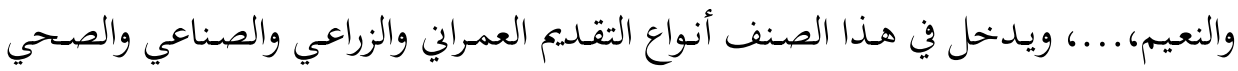

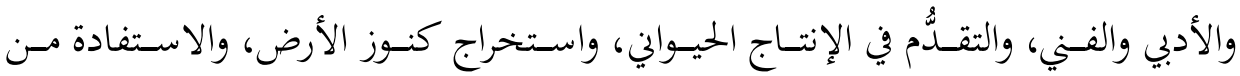

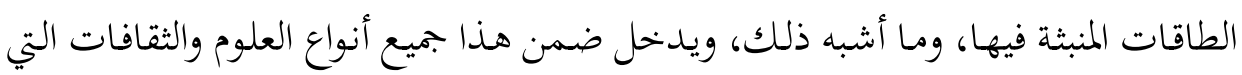

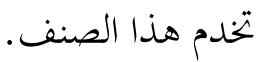

والصـنف الثاني: مـا يخدم المحتمع الإنساني، ويكون مـن الوسائل التي تمنحه سعادة

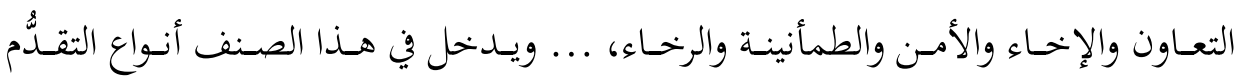

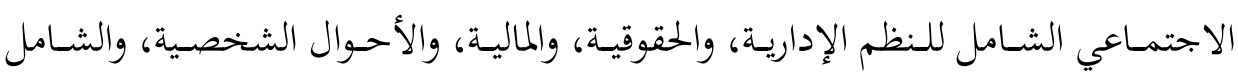

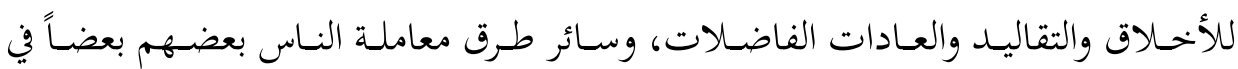
علاقاتم المختلفة، وكل أنواع الثقافات والعلوم التي تخدم هذا الصنف. والصنف الثالث: ما يأخذ بيد الإنسان فرداً كان أم جماعةً إلى السعادة الخالدة التي تبدأ منذ مدة إدراك الإنسان ذاته والكون من حوله، وتستمر مع نفسه وروحه الخالدتين إلى ما لا هاية له في الوجود الأبدي، ... ويدخل في هذا الصنف أنواع التقدُّم الفكري القائم على التأملات الحكمية، التي توصل الإنسان إلى معرفة الخالق، وسر وجود الإنسان، وغايته

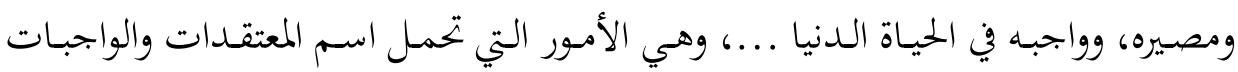

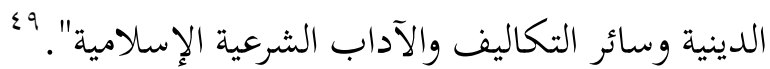

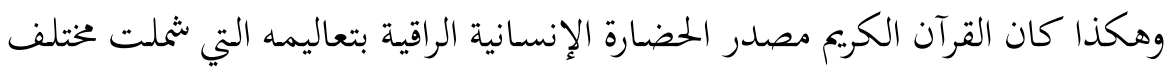

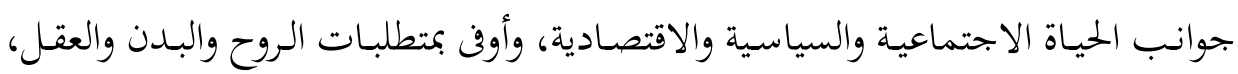
وعالج قضايا الفرد والجماعة والدولة، "فاعتنى بمحتلف القيم النفسية والاجتماعية والمادية

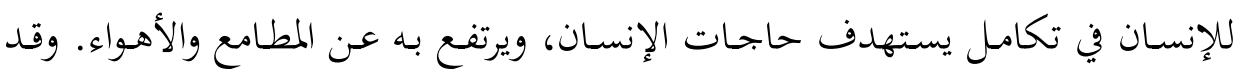

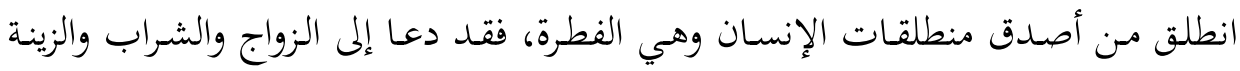

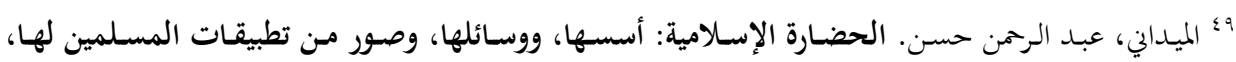

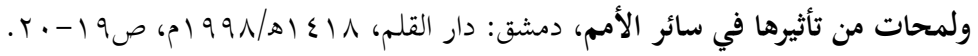




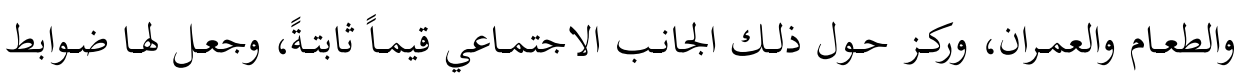

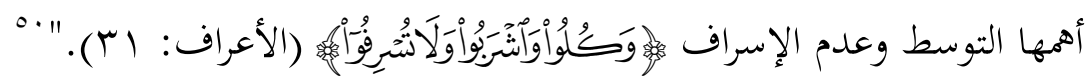

ويكق لنا أن نطلق على هذا الفقه اسم فقه العادات؛ الذي يُعلِّمنا أن التمتع بهذه

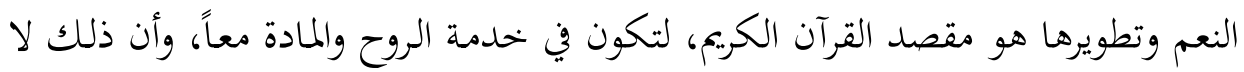

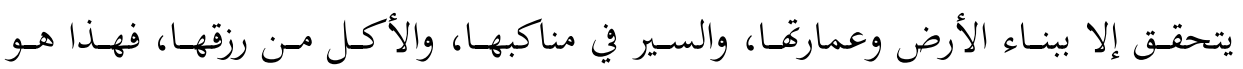

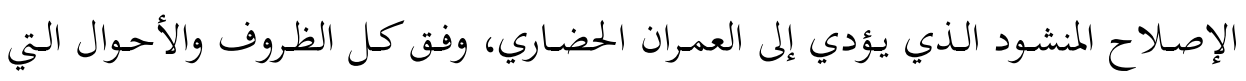

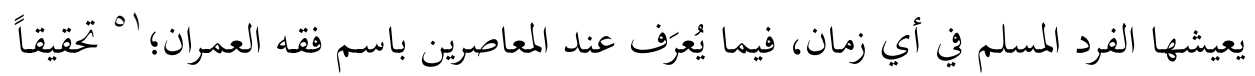

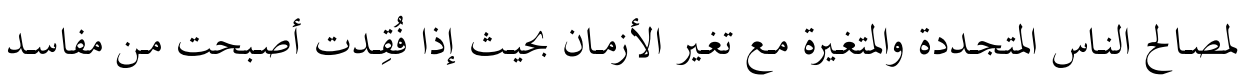
الأرض.

\section{سادساً: مقصد إصلاح العالم بإقامة العقوبات والزجر عن الاعتداء}

حافظ القرآن الكريم على هذه التشريعات بسَنِْه نظاماً عقابياً جزائياً فريداً، جمع بين

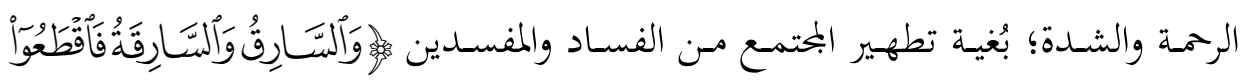

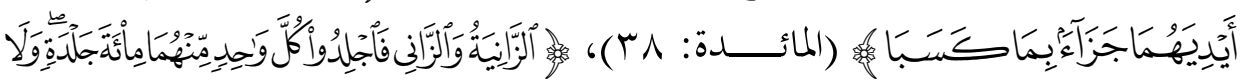

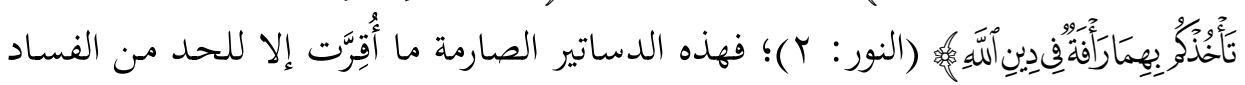
والإفساد في المحتمع الإسلامي.

وقد فرَّق القرآن الكريم بين عقوبات الجنايات تبعاً لتأثيرها في الصالح العام، ومقدار المصلحة المحتلبة، فشدَّد في عقوبات الجرائم التي تمس مصلحة المحتمع كله، وشرع حدورداً

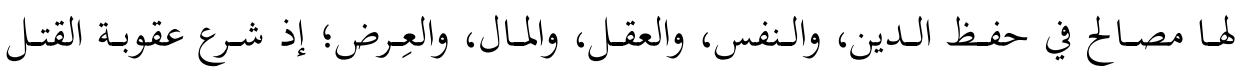

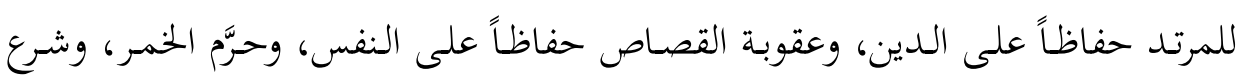

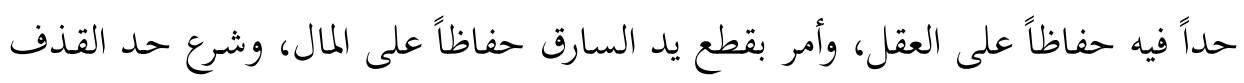
• إلجندي، أنور . مشكلات الفكر المعاصر في ضوء الإسلام، مصر : بحمع البحوث الإسلامية، سلسلة البحوث

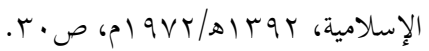

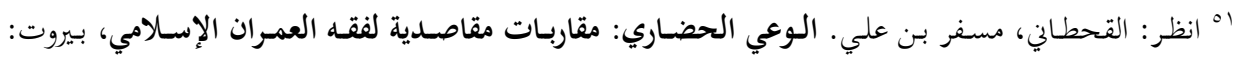

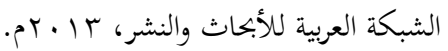




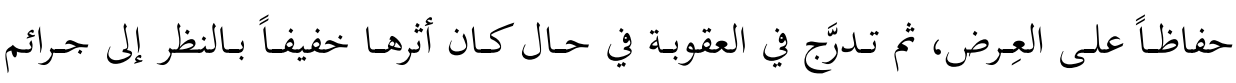

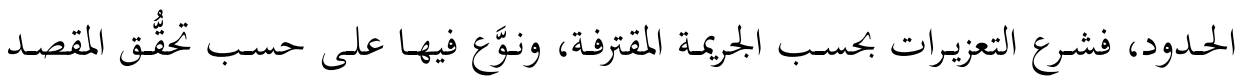

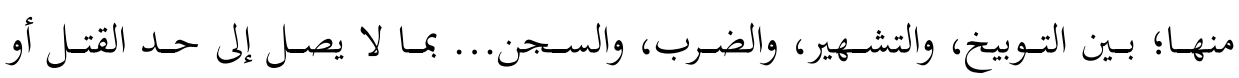
القطع. or

فالعقوبة في الإسلام مقصود منها حماية الجختمع، وهي ضـرورة اجتماعية اقتضتها

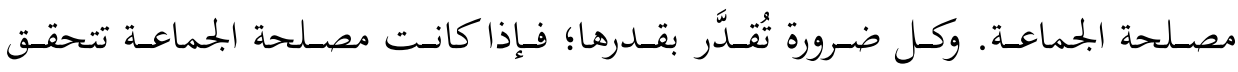

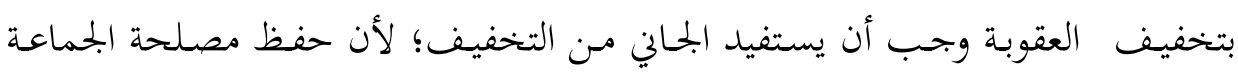

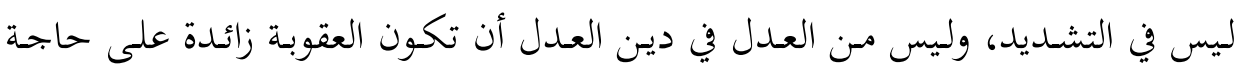

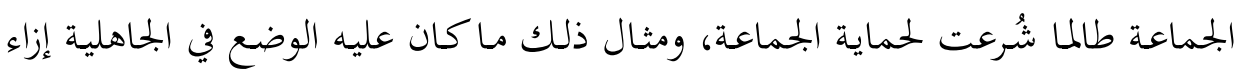

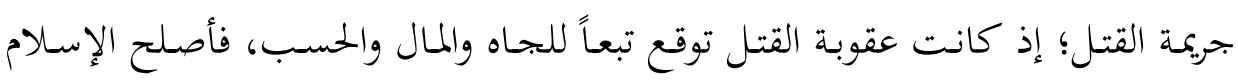

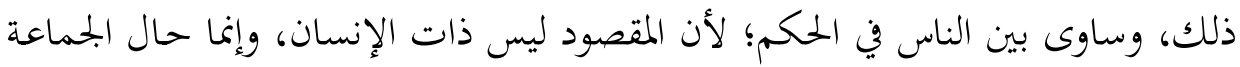
ومصلحتها. ذونساو بون

\section{خاتمة:}

يتبيَّن مُّّا سبق شدة اعتناء القرآن الكريم بالإصلاح حتى غدا مقصداً دينياً مُؤصَّلاً

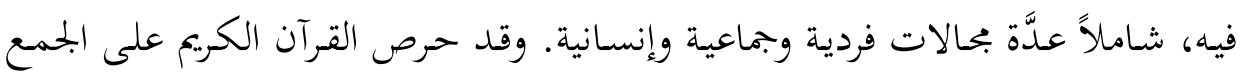

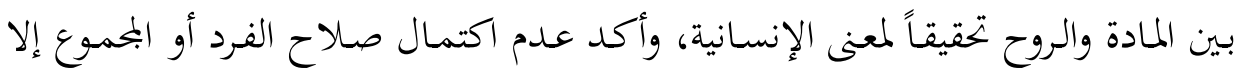

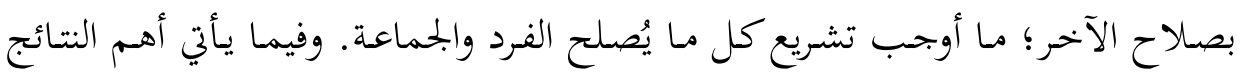
التي انتهى إليها البحث: الانحر الماحت

ا ـ الإصلاح عموماً هو دفع الفساد، وجعل الشيء صـالحاً؛ إنَّا بتعديله، وإَِّّا

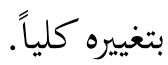

r. آيات الإصلاح في القرآن الكريم تعد دستوراً شاملاً، وتقنيناً كافياً لكل إصلاح.

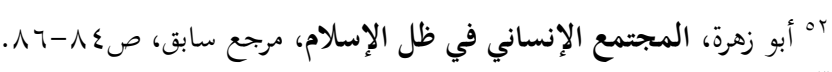

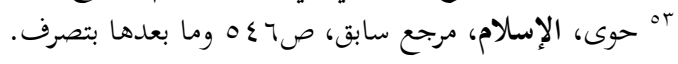


ب. الإصـالاح (اسـتقراءً للآيـات الآنـف ذكرهـا، ومـا يكملهـا مـن أحاديـث نبويـة شـريفة) هـو مقصـد قـرآي قطعي؛ سـواء بمـا يقصـده مـن عمـوم تحقيـق المصسلحة، أو بمـا يقصده من ضوابط لمذه المصلحة.

ع ـ المقصـود مـن الإصـلاح القـرآي هـو حفـظ نظـام العـالم باستـامة صسلاحه، ولا يتحقق ذلك إلا بصلاح الإنسان المهيمن عليه. ه. صالح الإنسان المهيمن على العالم يكون بصالاح تفكيره أولاً؛ لكي يتمكن من إصلاح ما بين يلديه. ج . إصلاح العالم من منظور القرآن الكريم هو تحقيق المصلحة للناس كافةً، والحفاظ عليها؛ فكل ما يقيمها مطلوب، وكل ما يُعوِقها مذموم.

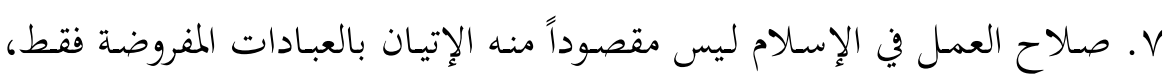
وإنما كل عمل يهقق عبودية مخلصة؛ من: سلوك، وقيم أخلاقية فردية وحضارية. م. للفكـر الجمـاعي أتر كبـير في تنميـة روح الإصـالاح وتحقيقهـا؛ لارتباطـه الوثيـق بالقيم الحضارية التي تسمو على كل قيمة فردية. وتأسيساً على ذلك، توصي الباحثة بما يأتي: ا ــ ضـرورة تفعيـل قراءة القـرآن الكريم بنـاءً على فكرة الجماعـة لا فكـرة الفـرد؛ أي التركيز على التفسير الموضوعي للقرآن الكريم إلى جانب التفسير الجزئي. ץ. وجوب توسيع معنى العبادة بحيث يصبح كل عمل مقصود منه الإصالاح عبادةً لها أجرها عند الله تعالى. ب. التشـديد -في كل إصلاح أو تغيير - على تحقيق المصالح للنـاس في ضوء القيم الحضارية، وعلى رأسها المساواة، والعدل، والرحمة.

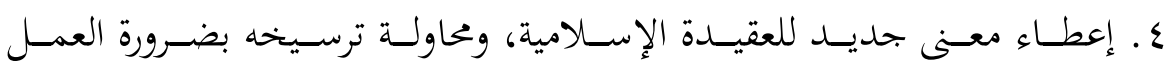
والاجتهاد، وبذل الجها لتحقيق كل ما هو نـافع، ولا سيما أن الإصالح يتيح لنا تحقيق الوسائل المشروعة حتى يكون التمكين. 